\title{
Article \\ Water Economics: An In-Depth Analysis of the Connection of Blue Water with Some Primary Level Aspects of Economic Theory I
}

\author{
Kalomoira Zisopoulou $^{1}$ (D), Dimitris Zisopoulos ${ }^{2}$ id and Dionysia Panagoulia $^{3, *(D)}$ \\ 1 Travaux Publics, Becket House, London SE1 7EU, UK; kal.evg.zisopoulou@gmail.com \\ 2 School of Environment, Education and Development, University of Manchester, Manchester M13 9PL, UK; \\ dimitris.zisopoulos@gmail.com \\ 3 Department of Water Resources and Environmental Engineering, School of Civil Engineering, \\ National Technical University of Athens, 15780 Athens, Greece \\ * Correspondence: dpanag@hydro.ntua.gr
}

check for updates

Citation: Zisopoulou, K.; Zisopoulos, D.; Panagoulia, D. Water Economics: An In-Depth Analysis of the Connection of Blue Water with Some Primary Level Aspects of Economic Theory I. Water 2022, 14, 103. https://doi.org/10.3390/w14010103 Academic Editor: Antonio Lo Porto

Received: 16 November 2021 Accepted: 16 December 2021 Published: 4 January 2022

Publisher's Note: MDPI stays neutral with regard to jurisdictional claims in published maps and institutional affiliations.

Copyright: () 2022 by the authors. Licensee MDPI, Basel, Switzerland. This article is an open access article distributed under the terms and conditions of the Creative Commons Attribution (CC BY) license (https:// creativecommons.org/licenses/by/ $4.0 /)$.

\begin{abstract}
An analysis of the following aspects of water economics was undertaken: Water as an Economic and Social Good, Modes of Government Intervention, Water Scarcity in Economic Theory and Agricultural Water Management Changes, with the support of over 300 sources. Emphasis was placed on the connection with primary aspects of economics, in contrast to the usual applicative expositions found in water economics literature. This is a novel approach comparing international bodies' definitions with economic theory at primary level which leads, upon occasion, to serious contradictions which were exhibited in broad lines. Furthermore, it compares the global implications of these definitions to the existing reality at country level, and a lack of bilateral consistency is exhibited. The uniform picture presented at global level is shown to become a non-uniform one at country level, where sharp variations in resources and availability form a competitive market between nations, and water-rich countries already possessing a competitive advantage are shown to attain a water-based comparative advantage as well. It is shown that although at country level water has a quasi-public good character with minimal private good market existence, this is achieved with the existence of a private goods market at international level via international trade in virtual water. A novel approach to management problems stemming from authority levels starting at global level and ending at farm level is analyzed and redressed by employing reality gap theory.
\end{abstract}

Keywords: water; trust doctrine; public good; social good; trust doctrine; government regulation; scarcity; management changes

\section{Introduction}

Water scarcity is manifested as physical scarcity or economic scarcity [1]. Physical scarcity occurs when water cannot satisfy all demands (including environmental flows) [2], which happens despite or because of the fact that the global system is interconnected hydroclimatically [3]. Economic scarcity is defined as the state where, regardless of physical scarcity, the socio-economic system is unable to utilize existing water in order to satisfy all demands [4]. This is because it may lack the storage, timely distribution and infrastructure development for access [5] or human, institutional and financial capital place a limit to water access [6,7]. Water was declared to be an economic good [8-10] and is considered to be a production factor in Computable General Equilibrium (CGE) modelling [11], where the Armstrong condition for non-substitutability can be sidestepped [12] in countries with import/export trading in virtual water [13] goods. The initial consumption phase of water was expansionary and was typically characterized by low total and marginal social costs, and elastic long-run supply of impounded water. At the same time, demand for delivered water was low but growing, and elastic at low prices-inelastic at high prices, with minimal 
competition and externalities [14,15], while agriculture was in a traditional development phase [15]. The present mature phase is characterized by high and rising total and marginal social costs, high and growing demand for delivered water, elastic at low prices and inelastic at high prices, intense competition and pressing externalities [14,15], while agriculture is in a commercial development phase [15]. Not paying attention to integrated technology levels leads to serious externalities; e.g., on a global scale, one of the primary examples is the loss of over $50 \%$ of irrigation water due to technical inadequacies, as seen in [16,17]. Another problem is the question of allocation to primary users-agriculture and industry-in terms of value and price policy, since in a model for water use in agriculture water is considered to be an input endowment [18], clearly favoring agriculture vis-à-vis industry.

It is obvious that when we refer to water economics the three main variables that exert influence on water economic behavior are existing water supply (ground and hydrological cycle), climate and consumption/population in the regime of physical distributions, interconnections and constraints as seen in [19]. Their relationship is not clear-cut as they exhibit two interesting characteristics: there are multiple interactions between many different components and multiple elements adapt or react to the pattern these elements create. These characteristics correspond to definitions of a complex system, to Rind's definition in analyzing the structure of climate [20] and Arthur's in discussing the economy itself [21], and water management is amenable to Forrester's System Dynamics Model [22], which is an approach designed for complex systems.

The purpose of this paper is to examine in depth some topics of the structural complexity of the economic aspects of water at primary level: Water as an Economic Good, The Trust Doctrine, the Market Good vs. Public Good Controversy and Government Regulation, Water Scarcity in Economic Theory, and Agricultural Water Management Changes. These aspects are presented in both the global and country level aspect, wherever possible, connecting in this way primary economic theory with the process aspect. Et ceteris paribus (all other things being equal) between these concepts is assumed for reason of simplification.

\section{Materials and Methods}

Water as an Economic and Social Good, Modes of Government Intervention, Water Scarcity in Economic Theory and Agricultural Water Management Changes are examined at primary economic level. In particular, these notions, as applicable to Blue Water, are directly connected, where possible, with primary sources of economic theory so as to obtain a direct connection with the foundations of economics and avoid the watering down and methodoriented omission and bias stemming from connections with directly applicable economics. This leads to a water economics framework which is conducive to theoretical development with water and economics connected at first principle level in conjunction with the physical aspects amenable to economic interpretation as seen in [19]. The methodology connections are displayed in Figure 1 in terms of the linkage of contributing factors to the main elements of this paper (colored boxes).

The structure of the paper can be seen below in Figure 2. 


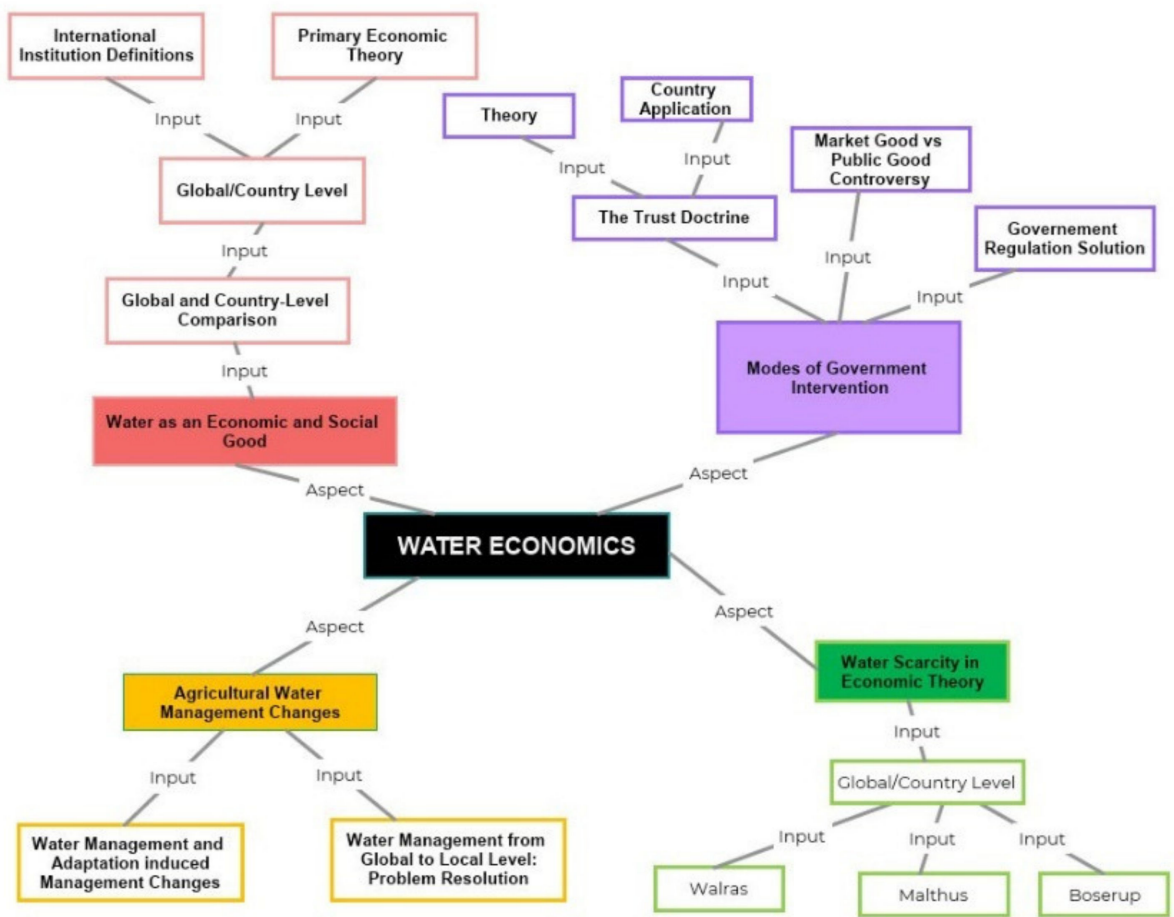

Figure 1. Methodology connection chart.

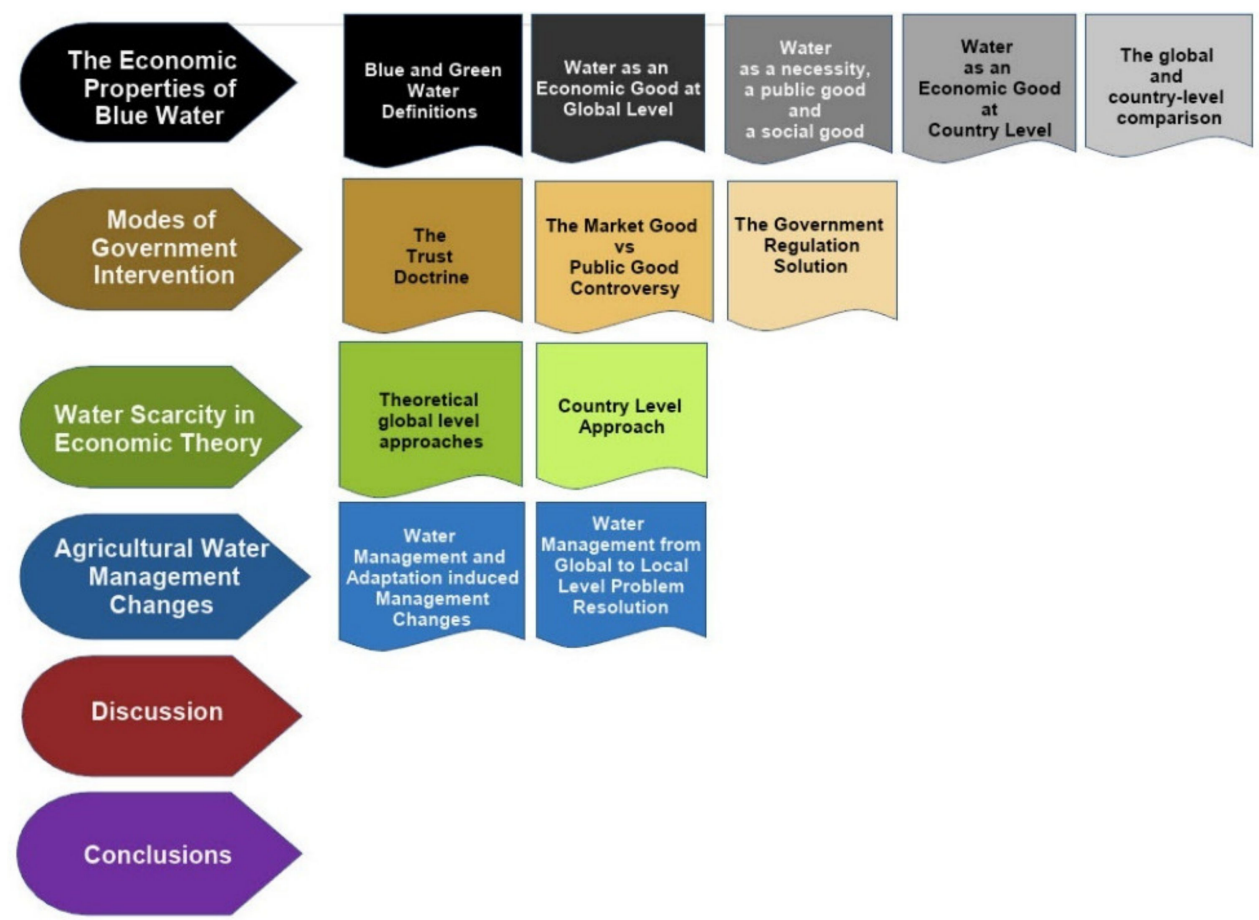

Figure 2. Structure of the paper.

\section{Results and Analysis}

3.1. The Economic Properties of Blue Water

3.1.1. Blue and Green Water Definitions

A variety of definitions for both blue and green water exist [23]. Falkemark's original definition is that incoming rainfall is partitioned into vertical flow and horizontal flow leading to aquifers and rivers which constitutes "blue water", while "green water" is the water in the root zone, the part of the upper vadose zone instrumental in partitioning rain 
and irrigation water into evaporation, transpiration, runoff and deep drainage [24], which is the source of plant nutrition [25]. A later, more precise definition [26], was given in terms of resource supply: blue water is the water in aquifers, lakes, and dams, and green water is the moisture in the soil; these are related to the liquid blue-water flow through rivers and aquifers and the green water vapor flow back to the atmosphere. Green water is divided into two parts [26-28], one part stored in the soil as moisture and another part in motion via the evapotranspiration process.

\subsubsection{Water as an Economic Good at Global Level}

Water had to be declared an economic good by fiat through the Organization on Economic Co-operation and Development (OECD) and through the Dublin Water Principles. OECD defined water as an 'economic good' due to the fact that (scarce) economic resources (human, capital, knowledge) had to be applied in order to make water available in the form, quality, location and timing needed by users [8] (pp. 18, 129). The Dublin Water Principles [9] (First and Fourth Principles) state that:

"Water is a finite, vulnerable and essential resource which should be managed in an integrated manner."

"Water has an economic value and should be recognized as an economic good, taking into account affordability and equity criteria."

The United Nations Conference on Environment and Development Agenda 21, Rio de Janeiro, Brazil, defined water as "as an integral part of the ecosystem, a natural resource and a social and economic good ..." "10] (Chapter 18).

It should be pointed out that water manifestly satisfies the Robbins definition of an economic good, within "the science which studies human behavior as a relationship between ends and scarce means which have alternative uses" [29-31] by itself, and nominally there was no need of its declaration by fiat as above.

The definition of an economic good requires the existence of conditions of relative or absolute scarcity. Relative scarcity in terms of neoclassical environmental and resource economics, pioneered for water by Faber [32], is defined in terms of quantity over available water resources as when "a good is scarce in relation to other scarce goods" [33]. Absolute scarcity corresponds to purely ecological economics [34], at some regional levels where water carries opportunity costs. This is a cornerstone of the Debreu model [35]; i.e., benefits foregone from possible alternative uses of the water [36] or additional monetary cost for an extra unit of the good, given scarcity in some settings and abundance in others; the water global supply is constant while its availability and distribution is inequitable, as in [19]. As it is an economic good, water has the character of opportunity in terms of a "course of action that is possible and worth pursuing" [37] or a "chance to meet an unsatisfied need that is potentially profitable" [38], more or less in similarity to unprocessed fuel deposits, as in [39]. At global level [40], the hydrological cycle presents deintensification in the 21 st century, with water balance on land and in the sea appearing to be lower; the main anthropogenic influence stems from the over-exploitation of groundwater, which has a visible effect on the rise in sea level.

\subsubsection{Water as a Necessity, an Impure Public Good and a Social Good}

The concept of need is seen to have three main characteristics: "first, the failure to satisfy someone's need is harmful to that person; second, in light of the resultant harm, there is an imperative to satisfy the need, i.e., an element of linguistic normativity already inheres in the word; third, given the preceding two characteristics, need cannot be reduced to the concept of desire or want (in its purely subjective modern semantics)" [41]. Adam Smith supported the concept of necessity in "By necessaries I understand, not only the commodities which are indispensably necessary for the support of life, but whatever the custom of the country renders it indecent for creditable people, even of the lowest order, to be without" [42] (Book V, Ch. II, pt. II, art. IV). As Winpenny points out "There are degrees of scarcity" among which 'need' is included, the lower bound of the scarcity bandwidth, 
which has a dual interpretation, that of actual physical need, which represents the closing of the gap between "what is" and "what ought to be" from an objective point of view and that of "felt need" which is based on people's subjective opinions and perceived trends and outlooks" [43]. More to the point is Beatty's definition of need as "the measurable discrepancy existing between a present state of affairs and a desired state of affairs as asserted either by an 'owner' of need ('motivational need') or an 'authority' on need ('prescriptive need') [44]. Regarding consumers, Samuelson distinguishes between what people "really want and need" [45] (p. 4) and particular attention should be paid to Thaler's economic theory of the consumer [46] and his position on perception of consumer utility maximization [47]. But then 'need' for humans, the water end users, requires per capita quantification of use to be defined, on a short-, medium- and long-term basis, where crops production is included, as seen below in Figure 3 [48] and in [49] as well as in the case of disasters [50]; Gleick et al. [51] recommend $50 \mathrm{~L} /$ capita/day but include studies where the bare minimum for survival is $1.8-5.0 \mathrm{~L} /$ capita/day.

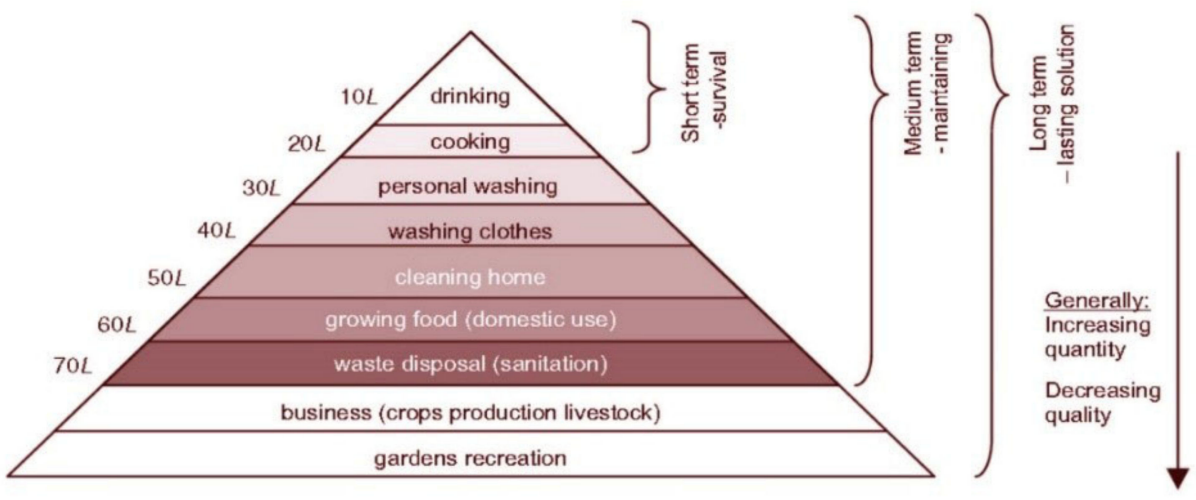

Figure 3. Short, medium and long term levels modified from [48].

As water is consumed by everyone both directly and indirectly, via agricultural goods and meat, it is a necessity as seen in [52], one with perhaps greatest scope and at a greater scale than any other good. Beyond the 'need' concept as seen above there is another impact: a form of an economic aspect of 'need' in terms of maintaining or augmenting a particular sectoral economy. This is seen on two levels:

1. At global level, water is needful in both agriculture and industry. Through its use measured by footprints in agriculture and industry, it represents additively a sizeable segment of the global tangible economy in terms of capital, both installations and monetary flow, as well as in terms of labor. Reduction of these sectors will have a global negative economic effect. Moreover, the competition between the agricultural and the industrial sectors constrained by the limits on quantity available will place a stress on the global economy. Considering that the 2030 U.N. hunger targets will not be attained [53], agricultural needs will be fueled and the increase in population and affluence projected by the Food and Agricultural Organization (FAO) [54] will fuel the needs of both agriculture and industry.

2. At country level, the situation above is exacerbated as water resources and availability are unequally distributed and so is increase in population and affluence. A good example is Sub-Saharan Africa [55], where water resources and availability are low, population increase is high and affluence is low.

Moreover, being a necessity good imbues it with different characteristics than a private economic good, drawn from those of public and social goods.

The fact that water as a good entails "impossibility of rejection" [56] implies that it has aspects of a public good [56], which is defined in [57,58] as non-rival (benefits are indivisible) and non-excludable (particular persons cannot be excluded from the benefits). This is reinforced by the fact that all water infrastructure works are financed by the state and their payment is carried over to the totality of consumers-which is more or less 
exactly the same as the directly or indirectly total taxable population-through taxation, either special or general, in the latter case reinforcing the definition in [57]. To be more precise, aquifer water is non-excludable and rival, and hence a common-pool good in the long term [59,60], which according to [61] is partially distinguishable from a public good in terms of social gaming, while shared irrigation water is excludable and non-rival and hence a club good [60]; both can be classified as impure public goods [62]. Modifying an optimality index concept due to Sandler [63], the larger the number of club-provided goods-relative to the total number of public goods, in this case common-pool + club goods - the smaller the risk of under-provision. In addition, according to the Kaul and Mendoza expanded public good theory [64], water has a special potential for being a public good (Def. 1) and, as it is a good with benefits that extend to all countries, people and generations, it has a special potential for being a global public good (Def. 3).

Social good "refers to services or products that promote human well-being on a large scale" [65] and clearly water is such a good. The case of water can be analyzed using assessments of present and future equity, i.e., who gets water and the fact that water has higher value than its monetary value [66]. As outlined in the case of cooperative technology [67], the main goal of resource allocation is the achievement of social efficiency [68], which is usually defined as in terms of Pareto optimality, and technical efficiency but depends also on an 'index of human development' [69]. Resource allocation systems yielding this result were initially designed by Hurwicz [70] and are based on incentive compatibility, individual rationality, information decentralization (to minimize information collection social costs), non-wastefulness (attaining the production frontier) and unbiasedness (achievement of the Pareto optimum of choice by income redistribution via lump sum supplements which must overcome income constraints so that social costs can be paid).

\subsubsection{Water as an Economic Good at Country Level}

Water availability, in terms of blue water and rain, income per capita, the structure of national production, exchange rates, international loans and external balances influence the nature of water as an economic good at country level. In addition, while the overall global hydrological cycle picture seen above [40] leads to a form of equilibrium, country level hydrological cycles [71] exist and differ sharply from country to country.

1. In countries with low or locally irreparably inequitable water regional availability, water public and social good characteristics are bound to become dominant as their role is augmented. A centralized state water policy is the only available remedy as the needed increase in water infrastructure is bound to be large, requiring state level resources and expertise, and its distribution is optimizable only on a country-level scale, which leads to increased state control in its provision. Good examples of this are the Southern African Development Community (SADC) countries [67], where the Human Development Index (HDI) rank among 177 countries ranges from 121 to 168, per capita freshwater withdrawals per year are all below the $1000 \mathrm{~m}^{3}$ /year and the water distribution favors agriculture; domestic consumption comes second overshadowing industrial use in most of these countries. The prime cause is considered to be inequity in the sectoral allocation of water [68] while water infrastructure funding in South Africa comes from the government [69].

2. Water impacts heavily on national social welfare in terms of poverty alleviation, employment and food security [72], as seen in a study regarding MENA countries [73]. However, social policy should be seen as a state intervention that "works in tandem with economic policy in pursuit of national social and economic goals" [74] and which places constraints on the level and methods of mitigating measures regarding a country's water policy both in general and at internal regional level as, e.g., basic needs, government debt and economic growth are intertwined [75]. The implications of this social policy include price stabilization of rural agriculture via government intervention, which in the case of poor countries is not considered distortionary (a report for Kenya examines spending 10\% of the government budget [76]), and a policy 
aim of self-sufficiency, which is not considered in this case a "bad economics" measure, as seen in a 2009 FAO report [77].

3. Countries that are rich in available water have a Ricardo type comparative advantage in the international trade of goods with medium/large water footprint over countries which are not, and according to the Heckser-Ohlin Model (H-O) [78], this leads to a degree of specialization in these goods within their production distribution. The need for water at national level gave birth to a substantial global scale virtual water trade network with strong plasticity (the ability to change structurally and functionally in time). In the period 1986-2008 the number of inter-country connections increased by $70 \%$. From the point of view of exporters, this remained constant after 1991, and doubled in volume [79], as can be seen in Figure 4 below.

4. This increases the exporting country's water degree of factor mobility, which according to the general equilibrium theory [81] is a component of growth as it increases water productivity. Moreover, agri-foods do not fall into the category of goods obeying Vernon's product cycle [82] in terms of low income countries, despite continuous innovative progress in agricultural technology [83].

5. At the same time the combination of per capita GDP growth, population growth and GDP growth for India, Sub-Saharan Africa (SSA) and Near East and North Africa (NENA), which are water stressed countries, is disadvantageous in comparison to Europe and North America which are main agri-food exporters as can be seen below in World Bank Data [84].

6. In fact, it can be seen that blue and green water and landmass rainfall do not form a closed system in terms of hemispheres. There is an import of rainfall to the northern hemisphere in a zone north of the equator due to the redistribution of energy via heat transport northwards beyond the equatorial ocean as the meridional overturning circulation also redistributes energy, by carrying heat northwards across the equator [85] as well as moisture which may attenuate due to global warming [86]. Also, Arctic ice melting leads to increased persistence of departures from normal precipitation during autumn and winter in heavily populated areas of the northern hemisphere [87]. This defines water-rich countries, with export epicenter on the U.S., versus water-constrained countries. Even in the case of a group of countries and their neighbors where relative and not absolute water abundance exists, the $\mathrm{H}-\mathrm{O}$ model is shown to be correct, e.g., for MENA countries and exporter countries such as Greece and Turkey [88]. In this case, Greece and Turkey specialized their comparatively advantageous production only partially (opportunity costs and comparative advantage depend on production levels and Greece is tied to the expensive euro while Turkey uses the inexpensive lira), and the other countries demonstrated that relative water endowments are important. The reason for this sensitivity lies in the Lerner-Pearce diagram [88] of a two-good economy comparing a necessity and a normal good.

7. It should be pointed out that water-rich countries are also, by and large, countries with a competitive advantage in the sense of Porter [89], which reinforces their comparative advantage generated by water abundance and vice versa.

8. Taking a page from microeconomics, Peteraf's concept [90] of the resource-based view (RBV) can be extended to country level and a resource is strategic if it possesses heterogeneity, imperfect mobility and ex ante and ex post limits to competition. Water can be classified as a strategic resource since countries with a comparative and competitive advantage use water heterogeneously, attaining "enduring and systematic performance differences among relatively close rivals" [91], as there exists a performance hierarchy between their economies and the strategic targets of water use.

9. Moreover, as water is part of the natural capital, it is included in a country's national wealth calculation [92]. It should be noted that its physical aspect, whereby value has to be associated with flow, may classify it as an extra-ordinary economic good [93], though there exists the counter-argument that direct values of flow, according to the value-flow concept [94], may be embedded in the water source. 


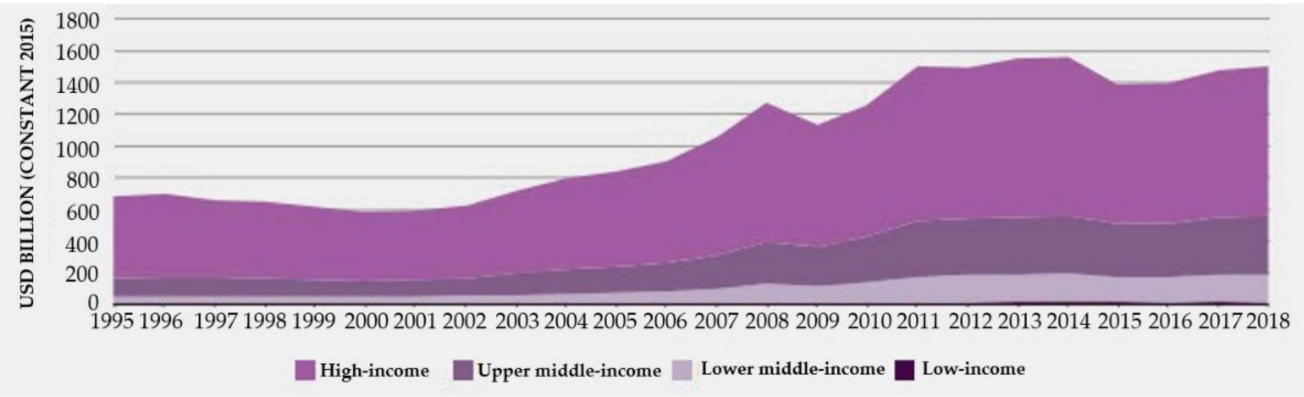

Figure 4. Agri-food exports 1995-2018 [80].

\subsubsection{The Global and Country-Level Comparison}

As can be seen above, there are two distinct and contradictory pictures of the economic properties of water depending on whether the point of view is global or at country level. In the first one, world population is the consumer in a format of one idealised indivisible assembly while, in the second one, population is segregated into competing sub-assemblies defined by sovereign states. In the second picture, which is more realistic than the first one, water at inter-country level, with countries being the consumers, is both rival and excludable and hence not an impure public good. Non-rivalry and non-excludability are applied at intra-country level as parts of national economic policies and within the economic means of the particular country, where the state is the local actor. This segregation creates a framework of 'haves and have nots'. This sets the inter-country virtual water trade in the role of a transnational actor in turning water to an impure public good at national level in conjunction with the sovereign state actor. In effect, an 'international water market' exists where water in the form of virtual water is traded as a private good at country level and gravitates to the actual consumers (as from the first point of view) under terms and conditions determined by the state which participates in the international water market.

On the other hand, there are very few descriptions of country level water markets [95-97]. Five of them are analysed in [42]: Australia's Murray-Darling Basin, the western United States, the Limari Valley in Chile, South Africa and North China. A recent analysis of water markets in the western United States [98] shows that in terms of overall water consumption, annually traded water amounts to $4 \%$ in Arizona, $2 \%$ in California and the same percentage in Texas. In addition, a study on Australia determined that water markets are likely to limit the effectiveness of water policies aimed at restoring natural flow regimes [99]. For water markets to be developed on a global scale, national legal frameworks must include legal conditions under which the government has a rule for water reallocation, the separation of water rights and landownership and cancellation policies for non-use [100]. At the same time, the insurance industry has started making inroads in potable water insurance [101]. A case of particular interest is that of the Chilean water code in the Chilean water market [102] determining water use rights (WUR), where water is "national property for public use" and its rights are tradable [103] as permanent, transferable water-use rights. These are granted to individuals under the restriction that the WUR issued may not alter or impinge upon an already existing WUR and comprise two types: 'consumptive', water that is not returned to the source after its use [104], and 'non-consumptive', water that is returned, e.g., in the case of a dam [105].

The failure of the 'international water market' framework to carry itself over at country level by influencing positively the creation of private water markets is due to the underlying fact that water is a necessity; thus, for welfare — and ultimately political—reasons there are limits on the capability and will of the state to back out from its measure of control.

\subsection{Modes of Government Intervention}

\subsubsection{The Public Trust Doctrine}

An important aspect of water is that of its key role in the support of life [106-108] and its nature as an "integral part of the ecosystem, a natural resource and a social and economic 
good, whose quantity and quality determine the nature of its utilization" [109] (p. 276). The state may, in some countries such as Kenya [110] (sub 5 p. 15), South Africa [111] and several states in the U.S. [112], hold water resources as a trust, a fiduciary duty of stewardship, under the public trust doctrine $[113,114]$, where 'public' may in general include present and future generations [115] or heritage [116,117]. However, in the U.S. the public trust doctrine does not impede sale of rights to the private sector [118] under the condition that the resulting public benefit is larger than the loss of social wealth [119]; it is challenged for lack of effectiveness in the case of a queuing system application [120] and as a threat to water rights [121,122], irrespective of whether they are considered to be property rights or not [123]. The implementation of the common law public trust doctrine alone in the protection of water resources is not a mandatory procedure but relies heavily on judicial goodwill toward the environment [124].

There are problems with the trust doctrine which stem from the fact that it has the potential to defeat the will of elected representatives [125], results in inappropriate discounting of environmental values [126] and raises questions on whether it could supply a comprehensive approach to natural resource management and whether it has further use in an era of environmental protection laws [124]. However, it has been used to take steps to protect water resources, even if doing so would conflict with some other interests (like private water rights) as seen in McBryde Sugar Co. v. Robinson, 504 P.2d 1330, 1344 [127]. In addition, states can sue to protect trust resources under their parens patriate powers [128] and members of the public (who otherwise have standing) may sue the state for failing to comply with its trust obligations over a particular body of water as seen in Nat'l Audubon Soc'y v. Super. Ct. of Alpine Cty., 658 P.2d 709, 712 (Cal. 1983).

\subsubsection{The Market Good vs. Public Good Controversy}

This led to the controversy between water being a market good or a priced/non-priced public good. Pro and con argumentation is based on a variety of reasons, e.g.,

1. Rural poverty in [129], the probability of private and public failure, the last being connected to management failure [31].

2. The mixed results and emphasis on the economics of water rights trading with very little attention given to the Water Code's impacts on social equity.

3. River basin management.

4. Environmental protection.

5. Resolution of water conflicts in the case of the Chilean water framework [102].

6. The value generated by irrigation in the production process [130].

7. The fact that the choice between public and private water delivery includes the cost of funds, i.e., the social cost of taxes, transaction costs, the difference of efficiency, which did not favor private delivery, and the potential political cost of privatizing [131].

8. The argument that the combination of the public trust doctrine and the dual nature of water as an economic commodity and as global human right leads to water being a public commodity [132].

9. The failure of the South African Government to take responsibility for the acid mine drainage (AMD)-caused water pollution [133] and the existence of rule-setting definitions of water stewardship by businesses [134].

\subsubsection{The Government Regulation Solution}

A middle-of-the-road solution with a great possibility of success is the position that water is a good requiring state supervision/regulation [135], which is less restrictive than public trust stewardship but more restrictive than an open private good market. Water is usually a heavily regulated commodity, presumably by the state, due mainly to the fact that the natural characteristics of water, chief among which the fact that it is a natural monopoly. This does not allow for the creation of competitive markets that could establish economic value [136,137], despite the OECD policy of "user pays" [138] most recently applied in Brazil $[139,140]$. This leads to the fact that when a water charge is 
imposed, which is equivalent to a tariff [141], it is usually not commensurate to either its otherwise perceived economic value or to its cost of supply, due to subsidies or government financing of infrastructure passed on to general taxation. Added to that, a dominant state regulation regime may employ Pigouvian taxes $[39,142]$ at source which are transmitted to any user level in order to subsidize shortfalls, water conservation research and/or storage expansion due to population increase or the opportunity cost of the water used, i.e., the drop in the level of water reserves. This imposition is due to an effort to ameliorate the impact of Hartwick's Rule [143,144], which prima facie does not include the costs of redressing the environmental impacts of resource extraction [145], or to impede PigouDalton Transfers [146] to the general population.

\subsection{Water Scarcity in Economic Theory}

\subsubsection{Theoretical Global Level Approaches}

In fact, scarcity in general was first mentioned by Malthus. Scarcity "implies a strong and constantly operating check on population from the difficulty of subsistence" [147] (p. 20), the check control being imposed by agricultural production [148], and is considered to be one of the basic assumptions of economic theory [149] (p. 4), contra seen in [150], while Ricardo in [151] attributed the check control to declining land quality. Both types are subdivided into stock and flow scarcity [152]. Malthusian stock scarcity, applicable to resources of uniform quality with an ultimate limit as noted above and in Hotelling [153], refers to a total available resource stock constraint. Malthusian weak flow scarcity refers to the limit on the available resources and on the extraction rate [152], while Malthusian strong flow scarcity refers to the weak one plus a constraint on total resources [154]. Ricardian flow scarcity is the case where average costs depend upon the rate of extraction and Ricardian stock scarcity is flow scarcity plus the total extracted to date [152]. Under additional assumptions, the theories of Malthus and Hotelling can be reconciled by the employment of an exhaustible resources model in a dynamic input-output framework [155].

According to Walras, scarcity refers to goods "capable of satisfying a want which does not exist in such quantities that each of us can find at hand enough, completely to satisfy his desires" [156], a view adopted by Robbins [157]. Special attention should also be paid to Montani's theory regarding the case of land scarcity [158], which is attributed to changes between profits and wages while produced quantities are held constant.

However, resource scarcity theory development is based more or less on Malthus and water scarcity at regional level is not a new phenomenon as a two millennia study shows [159]. It should be pointed out that technology is not an instrumental economic variable in the Malthusian theory, where it is assumed to be part of the et ceteris paribus assemblage. Counterarguments were initially raised by Boserup [160], where, as mentioned by Kaldor in the foreword to her book, technological change manifested as "agricultural intensification" will negate the Malthusian catastrophe. Attention should be paid to the existence of the Jevons' paradox 'rebound effect', where yield-increasing innovation may lead to increased demand if it is accompanied by lower prices [161,162]; an example of this effect could be encouragement of deforestation, a characteristic problem of incentivebased land sparing policies (LSPs) [163], whose transmission can be stopped only with inter-regional market segmentation [164]. Also, these counterargument theories do not take into account the problems of agricultural land distribution or climate, which can be ameliorated only by the import of high virtual water-content products, although the fragile economies of poor water-stressed countries may place a limit on this process as trade balances may teeter dangerously. Hayami and Ruttan [165] consider technological change to be 'induced innovation'. But 'innovation' is the emblem of the Green Revolution regarding land use land change with intent to be used in agriculture based on the Borlaug hypothesis of increased productivity, a global level theory, which has, under particular conditions, environmental impact $[166,167]$ as well.

There are two types of scarcity, general and relative [168]. The first type is Malthusian and refers to actual use of a resource in relation to a want, a need, or a requirement and 
the second type, due to Robbins, refers to the alternative use of a resource in relation to competing wants [169]. Moreover, according to Ohlsson and Turton, there are two orders of water scarcity, physical scarcity being the first order, and society's inability to manage this scarcity being the second one [170].

\subsubsection{Country Level Approach}

It should be pointed out that Falkenmark's classification of the state of physical water expendable resources into water adequacy, stress and scarcity [171], on the basis of which countries are classified, depends on demographic parameters only [172].

In terms of export-import change balance for the 1995-2018 period low income countries had a net import position in fruits and vegetables of $+259 \%$ and in meat (which has a very high water footprint) and fish of $+262 \%$ [80]. As can be seen below in Figure $5 a, b$, there is a gross correlation in terms of physical water scarcity and poverty also seen in [173].

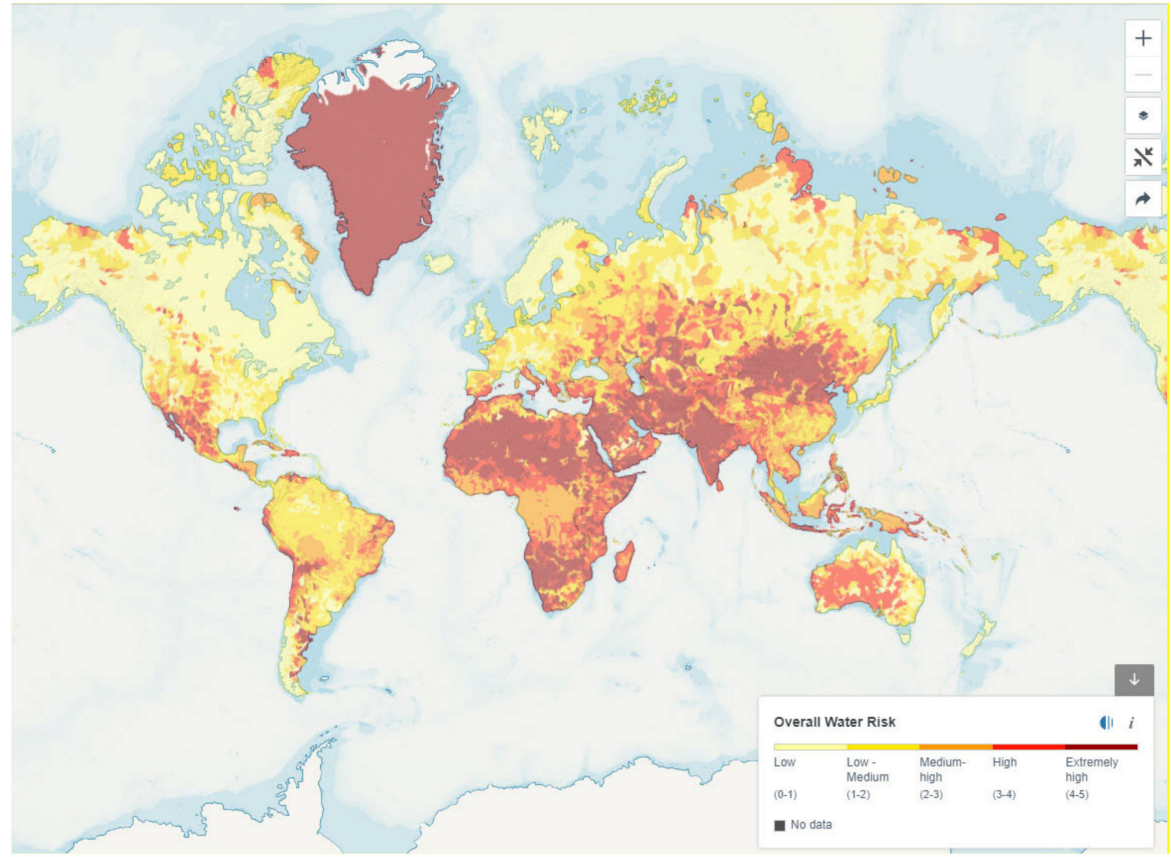

(a)

Low income Lower middle income Upper middle income High incon

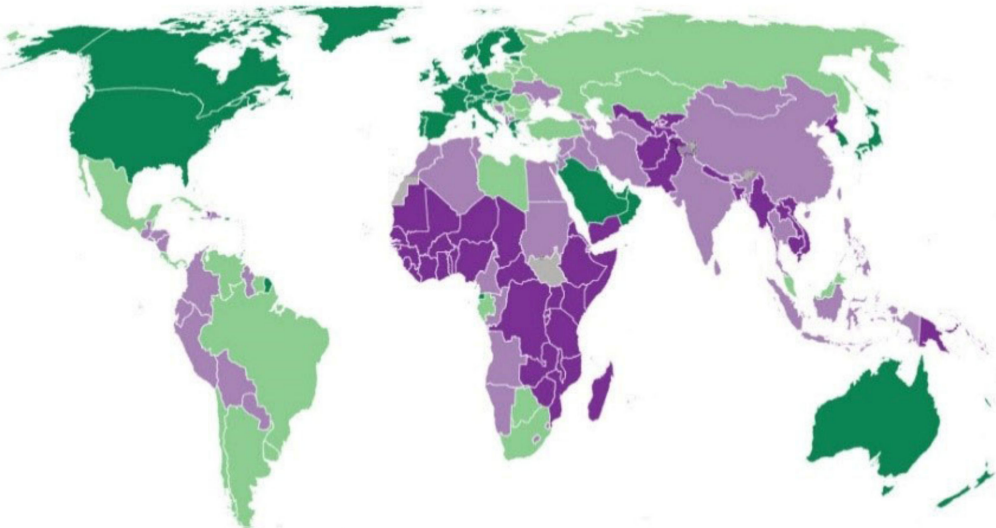

(b)

Figure 5. (a) Water Risk Atlas [174]; (b) income distribution, 2007 [175]. 
The export-import balance interferes with the classical definition of the expenditure approach to GDP, $\boldsymbol{Y}=\boldsymbol{C}+\boldsymbol{I}+\boldsymbol{G}+(\boldsymbol{X}-\boldsymbol{M})$. This implies that to keep GDP constant when the export-import balance is reduced, a counterbalancing increase must occur in the sum of $C+I+G+X$; this is easier said than done as it requires time and there many impeding factors to growth for each of the variables considered. Further, regarding developing countries which have a high degree of import dependence, currency depreciation is not a solution [176]; the trade imbalance often leads to official borrowing to finance deficits in a pegged exchange rate economy [177] increasing the national debt.

The Borlaug hypothesis at micro level purportedly reduces to the 'subsistence theory'; i.e., smallholders' objectives are constrained to 'limited wants' and 'full belly', which may not be the case as actual preferences most probably extend beyond those [178] at the cost of increased deficits.

A viable solution is to increase innovation which targets productivity increases in the agricultural sector. However, innovation requires the existence of intermediaries, as seen in a study of the Dutch agricultural sector [179]. An 'intermediary' in innovation process application is defined to be "An organization or body that acts as an agent or broker in any aspect of the innovation process between two or more parties. Such intermediary activities include: helping to provide information about potential collaborators; brokering a transaction between two or more parties; acting as a mediator, or go-between; bodies or organizations that are already collaborating; and helping find advice, funding and support for the innovation outcomes of such collaborations" [180]. This may entail the risk that intermediaries will play a non-neutral 'steering role' [181,182].

According to Wolfe and Brooks, a third order of water scarcity exists which may be aided by the implementation of 'soft water paths', centered on the process of starting from some defined future point and working backwards to find a feasible and desirable way ("a soft path") between that future and the present [183], which is in effect a sustainability approach. This is an approach which is applicable to developing countries [184] and useful in the case of droughts in a water-scarce environment [185].

Water scarcity is demand driven [186,187], under the assumption of optimal water resource physical as well as managerial infrastructure, since it depends on

- Population and Gross Domestic Product (GDP) growth, which increases demand for irrigation water to meet food production requirements and household and industrial water demand [188];

- Water use efficiencies which, when realized in the form of irrigation efficiencies (IE), rarely result in the public good benefits of increased water availability [189], as increases in yield are linearly related to increases in irrigation [190] and water recycling technology [191] or climate driven [192,193].

Also, it could be that, while resources nominally satisfy demand in total or in part, in reality the infrastructure is so sub-optimal that demand cannot be actually satisfied or users are worse off, creating in effect a condition of demand-driven water scarcity or an increase of this state [194-197]. It is quite important that the 2012 Global Water Security Assessment reported by the U.S. Intelligence Community includes a detailed analysis of nine selected water basins of U.S. allies using the criterion of river basin management capacity, "an assessment of the strength and resilience of institutional factors, such as treaties and river basin organizations that can provide stability, increase cooperation, and mitigate political grievances over water" which is part of the managerial infrastructure. This report graded Indus and Jordan as 'adequate', Mekong, Nile and Tigris-Euphrates as 'limited' and Amu Darya and Brahmaputra as 'inadequate' [198].

Investing in water is a path to economic growth and jobs, as a number of studies find correlations between water-related investments and economic growth [199]. Water becomes a 'bottleneck' (congestion) for growth if at least one of the following conditions set by Howe occurs: "(a) when water inputs into important production processes are fixed in relation to output; (b) when water supplies are fixed or only capable of slow and/or costly expansion; (c) when supplies are rigidly allocated among uses over time; (d) when 
water is a controlling factor in human health and productivity" [200]. Water is a congestible nonexcludable good according to Barbier [201], based on the approach seen in Barro [202], while congestion is examined in the CGE approach of Hertel \& Liu [203]. Guarino appraised the case at a global level [17] where losses in crop yields due to climate changes affect Middle Eastern economies [204,205] and impact negatively on GDP in Saudi Arabia [206].

As water permeates important sectors of the economy such as agricultural production, mining and industry [207,208], its scarcity is bound to impede economic growth-as seen in Dasgupta [209], and in the case of Africa [210], in a World Bank Group in-depth analysis [211] and in economic development initiatives [212]. Likewise, rainfall variability and real GDP growth in Zimbabwe are completely correlated [213], including negative impact due to rainfall reduction. In China industrial development cannot be stable unless the ratio of water resources and the human capital growth rates are less than the ratio of human capital and water output flexibility [214]. In contrast, Damania finds no significant impediment [215].

A scenario not usually examined is the case where Ohlsson and Turton's [170] first order of scarcity is so dominant that optimization of water management plays virtually no role, as augmenting the water infrastructure is way too expensive for a country's economy and pricing policies will not yield substantial results. Hypothetically, this is a case where a country's only critical area region which is amenable to agricultural utilization has reached Gleick's limit of 50 L/day for "drinking water, sanitation services, bathing, and food preparation" only [216], plus agricultural water resources which can service a completely inadequate fraction of the critical area. If this trend seems to be permanent, the only economically viable solution is the massive development of other resources so as to counterbalance the food import problem.

\subsection{Agricultural Water Management Changes}

\subsubsection{Water Management and Adaptation-Induced Management Changes}

Definitions of management vary. The latest one is "Management, to repeat, means getting things done through other people-whether that be on the people plane (leading and linking) or on the information plane (controlling and communicating)" [217]. The most pertinent is "Management is the process of achieving organizational objectives, within a changing environment, by balancing efficiency, effectiveness and equity, obtaining the most from limited resources, and working with and through other people" [218]. Public management is defined by Moore [219] as "conceiving and implementing public policies that realize the potential of a given political and institutional setting" where 'potential' was termed by him in 1995 [220] to be 'public value'.

According to the United States Department of Agriculture (USDA), "Water management is the control and movement of water resources to minimize damage to life and property and to maximize efficient beneficial use. Good water management of dams and levees reduces the risk of harm due to flooding. Irrigation water management systems make the most efficient use of limited water supplies for agriculture" [221]. Globalwaters.org defines agricultural water management (AWM) as "seek(ing) to use water in a way that provides crops and animals the amount of water they need, enhances productivity, and conserves natural resources for the benefit of downstream users and ecosystem services" [222]. A more tractable approach is found in [223] regarding water resources management which is defined as "the whole set of technical, institutional, managerial, legal and operational activities required to plan, develop, operate and manage water resources". This is a case where the economist's view is "connected with water use efficiency, cost recovery, the creation of water markets, tradable water rights, and privatization of water supply", while the politician's view is "solving conflicts over water, and attaining national objectives such as economic growth, poverty alleviation, employment generation, and food security" [224].

According to Armstrong [225], management change is "any changes in structure, management, employees, processes, and other related activities" and the change considered here is one in strategic management, which is defined as "the process of evaluation, 
planning, and implementation designed to maintain or improve competitive advantage. The process of evaluation is concerned with the external and internal environments" [226].

One of the main issues is that of irrigated agriculture adaptation to the foreseeable climate change impacts, e.g., in Southern Europe [227], a change that will happen at farmer level but presupposes managerial/institutional adaptation/change as called for in [228,229]. In [230], different water management options are considered through four alternative allocation methods across users regarding water mobility and user prioritization:

1. Limited mobility (LIMIT) - only a fraction of $5 \%$ of total water resources can be re-allocated across users based on scarcity price information.

2. Agriculture-last (AGLST) —only the use of irrigation water is constrained whilst non-crop users are free-riders.

3. Full allocation (FULL) - the existence of one single water market within a region in which all water resources are tradeable between any given self-abstracting sectors.

4. Fragmented markets (FRAGM) - water withdrawals for crops and non-crop sectors are completely separated, and the reduction in water availability for each is proportional to the overall required reduction in unconstrained withdrawals.

In [231], an integrative framework that can fill information gaps and contribute to a systematic analysis of performance is found to be useful. In [232], adaptation needs include: (a) improving resiliency and adaptive capacity; (b) response to changes in water availability; (c) response to floods and droughts; (d) response to increased irrigation requirements; (e) response to changes in agricultural land use; (f) response to deterioration of water and soil quality; (g) response to loss of biodiversity These will in all probability lead to structural changes in the administrative/management sequence. In the case of water scarcity [233], the pertinent sections of the administrative/management sequence must focus on specific objectives according to the causes of water scarcity, which, if they are long term, will justify management structural changes.

Changes in an organization require an agent of change who must have the necessary qualifications for successful change leadership and management [234]:

1. Hemophily - degree of similarity between the change agent and organization members.

2. Empathy-understanding the feelings of another person.

3. Linkage- the extent that the change agent and the members of the organization are connected by collaborative activities.

4. Proximity - the extent of both physical and psychological closeness between change agent and members of the organization.

5. Structuring - the ability of the change agent and organization members to clarify and organize the change plan.

6. Capacity-the organization's ability to provide the resources necessary for the change.

7. Openness - the extent to which the change agent and the organization members hear, respond to, and are influenced by one another.

8. Reward-the positive outcomes that are beneficial to both the agent and the members due to the change.

9. Energy - the amount of physical and psychological effort the change agent and organization members are able and willing to spend on the change process.

10. Synergy - the extent to which the previous nine factors interact positively with one another.

In terms of irrigation water as a common pool resource, the structure of management, if left in a classic form, may, by succumbing to the free rider phenomenon and to reckless overexploitation as, e.g., in [235], lead to Hardin's 'tragedy of the commons' unless there is a change management event and participatory processes [236] are applied, e.g., the actionarena outlined by Ostrom [237]. Another change management approach is the employment of system dynamics modelling (SDM) based on Forrester's work [22,238] where in place of Ostrom's action-arena a more formal 'interaction space' is employed [239]. SDM has been used with success in water management [240,241], as seen in sustainable water resources management and agricultural development in the Volta River Basin, Ghana [242], in the 
development of financially self-sustaining management policies for water and wastewater systems [243], in community-based water planning in the Middle Rio Grande [244], in the management of lake water quality at the watershed scale [245], in the sustainable utilization of water resources in China [246] and in supporting decision-makers in irrigation water management [247].

Introduction of new water conservation measures in irrigation as a change management event sometimes backfires as in the case of Kansas, where traditional center pivot irrigation systems were changed to higher efficiency dropped-nozzle center pivot systems but water consumption increased due to crop pattern changes [248].

\subsubsection{Water Management from Global to Local Level: Problem Resolution}

The usual approach to agricultural water policy-making is public management in one form or another, which is part of an economic/political/administrative/managerial chain going from the global level down the farmer level as seen below in Figure 6.

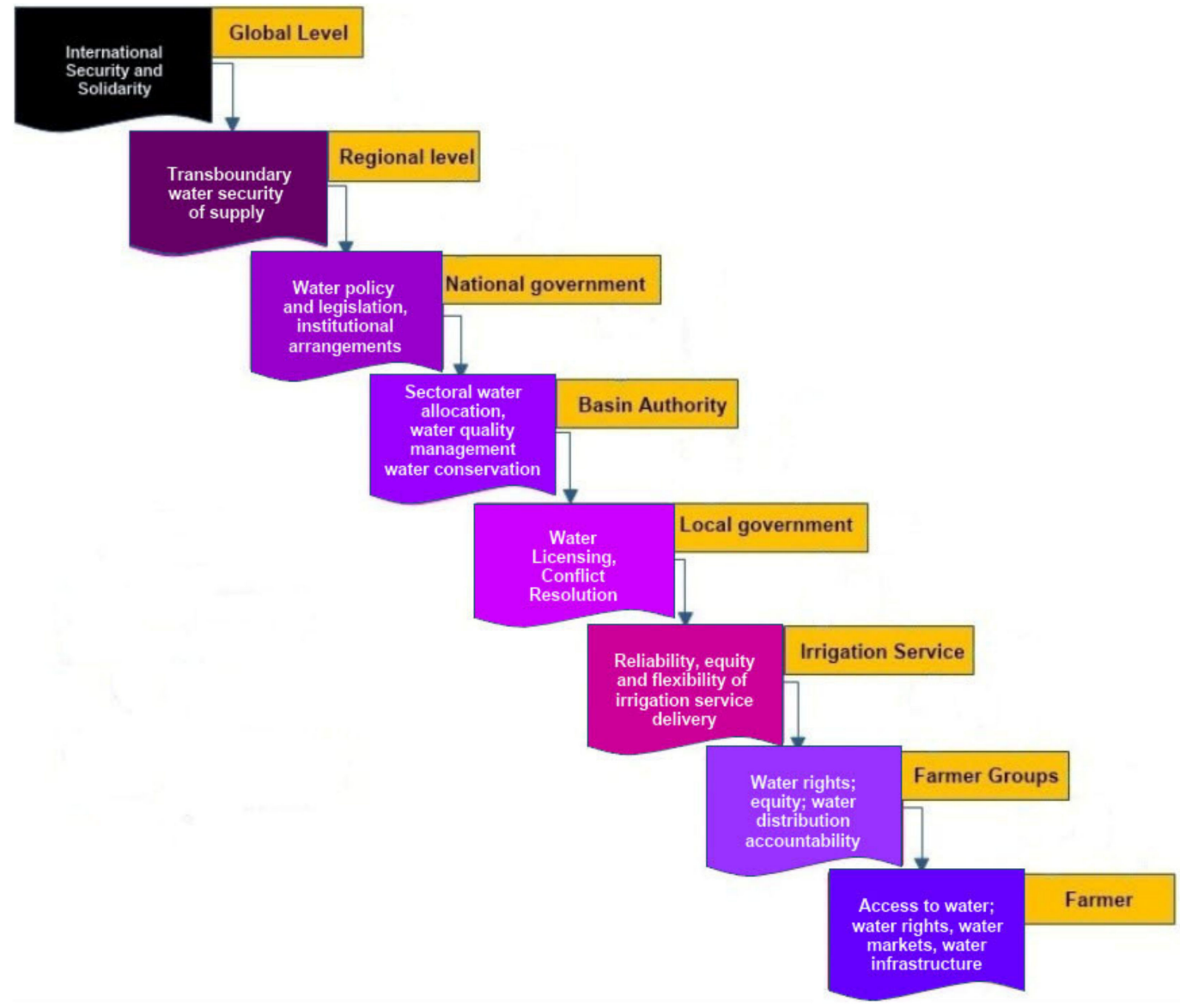

Figure 6. Global water management chain image constructed from [249].

The chain in Figure 7 has enormous extent in terms of de-scaling and increase in the number of regions considered, while at the same time their individual size decreases as levels move downward. Moreover, the characteristics of each segment differ and therefore at every level there is need of customization of directives coming from above with respect to differing sizes and the number and nature of characteristics taken into account while they are 'in loco administrare'. Hence descriptive variables vary/increase from level to level and data/information regarding scale and the idiosyncratic characteristics of each region plays the central role. In essence, successive levels handle aspects of central policy so that these may be effective at their level and at those below it; otherwise, as the level becomes more de-scaled and detailed on its way down, failures will increase. This requires a strategic 
change of choice from concentrating at their own level only, where strategic choice is a "transformational process in which organizations adapt to environmental changes by restructuring themselves in an intentional, rational manner" [250]. Unless this change management occurs, there exists a distinct possibility that, considering the number of linkages and the bilateral communication needed, a serious case of a hybrid of the reality gap-that between planning and reality—will be manifested, as seen in Heeks [251,252] and applied in $[253,254]$ and elsewhere in terms of IS systems. This can be seen below in Figure 7.

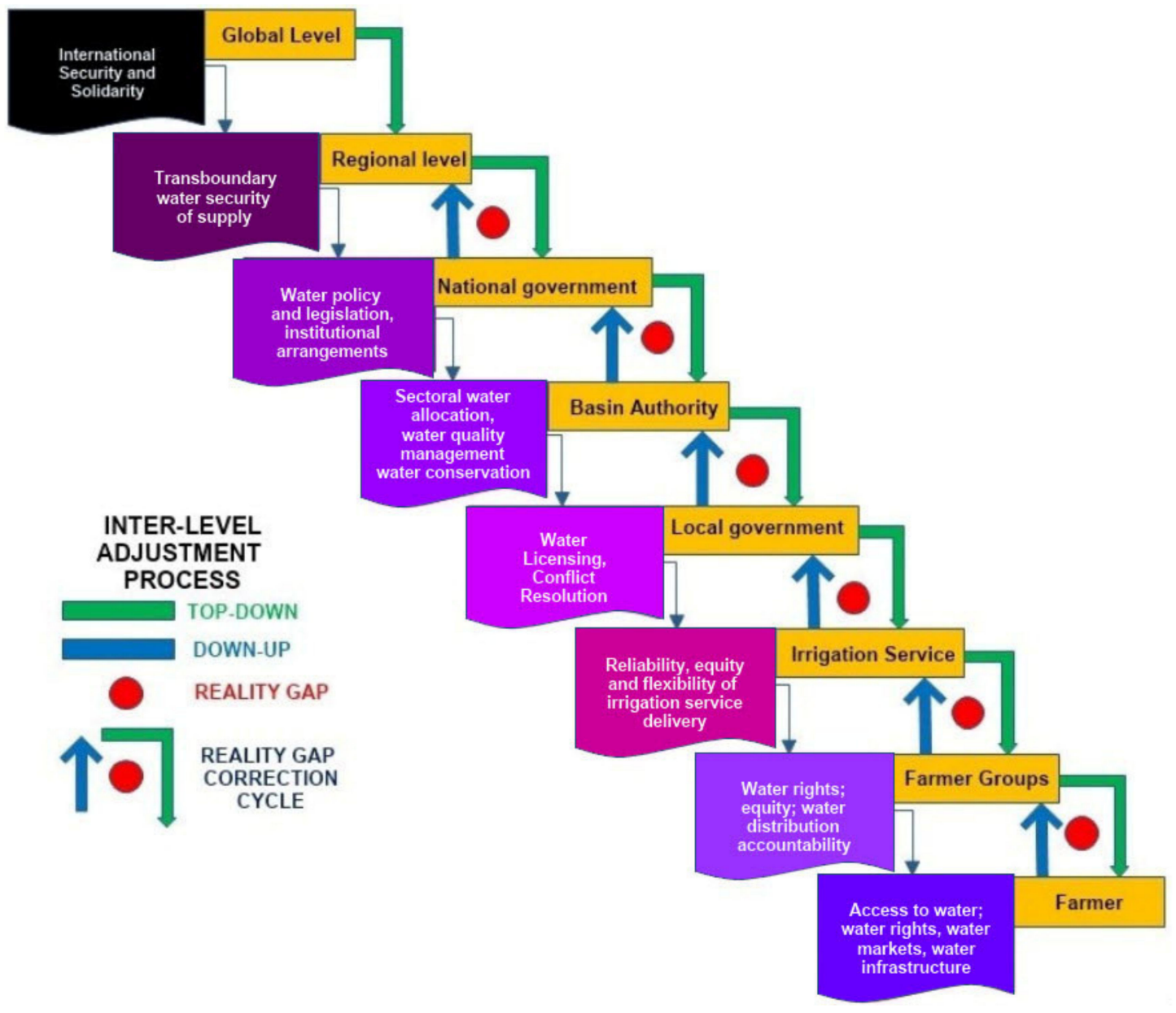

Figure 7. Reality Gap correction.

Reality gap corrections in this case can be processed in either a top-down way [255] or a bottom-up one [256], each one having its advantages and disadvantages. The realitygap correction cycle at every level may be realized using successive applications of the Lewin model [257] of unfreezing, changing and refreezing, where the changes will come from discussions between the state and private stakeholders and objective appraisals of data projections and subsequent enforcement by coercion via fiat (imposition of rules and regulations). In effect, what is described here is "iterations between theory and data to create a complex model of strategic change processes in a loosely coupled system" [258]. HR problems in the chain can be addressed in a similar way.

\section{Discussion}

There are two contrasting points of view regarding the categorization of water as an economic good, based on the interpretation of the fourth Dublin principle. At one extreme is the concept of allocative efficiency, i.e., "allocation to where the highest economic gain results from one more unit of water" which has a purely economic character. At the 
other extreme is the concept of allocative equity "spreading of income across sectors and societal groups" [259], whose resolution has been attempted by, e.g., distributive justice, as seen in $[260,261]$.

The first interpretation is based on the regular demand-supply mechanisms only, including consumer's sovereignty: water must be priced at its economic value while market forces will ensure its optimal or efficient [262] allocation, as seen in [263]. Consumers' sovereignty is a term analyzed by Hutt in [264] (pp. 23-24), where the consumer is "sovereign when, in his role of citizen, he has not delegated to political institutions for authoritarian use the power which he can exercise socially through his power to demand (or to refrain from demanding)" [264] (p. 257). Hutt described it as "the controlling power exercised by free individuals, in choosing between ends, over the custodians of the community's resources, when the resources by which these ends may be served are scarce" in [265], where, in the case of water, the actual custodian is usually the government. This approach was also shared by von Mises as "Neither the capitalists nor the entrepreneurs nor the farmers determine what has to be produced. The consumers do that" [266] (pp. 269-270) and is based on "mechanisms for getting people what they want, no matter how these wants were acquired" [267]. Arrow supported this position in "Condition 2: Positive association of social and individual values" [268] (pp. 25-26) and "Condition 4: The social welfare function is not to be imposed" [268] (pp. 29-30). This should be viewed in tandem with the following dictum: "In a market system, economic values of water, defined by its price, serve as a guide to allocate water among alternative uses, potentially directing water and its complementary resources into uses in which they yield the greatest total economic return" [269]. Consumer culture supports consumers' sovereignty: the "primary economic image offered to the modern citizen is not that of the producer but of the consumer" [270] (p. 103). Coupled with general ignorance about the ecological consequences of consumption choices, this leads to overconsumption of water [271]. Overconsumption is deemed to be anything above sustainable consumption, which is "the amount of consumption that can be continued indefinitely without degrading capital stocks including natural stocks" [272] (p. 8). This is contrary to the classic Schumpeterian view that "It is, however, the producer who as a rule initiates economic change, and consumers are educated by him if necessary; they are, as it were, taught to want new things, or things which differ in some respect or other from those which they have been in the habit of using" [273] (p. 38) where 'producer' should be substituted by 'custodian'.

There is an inherent problem in the case of water in this scenario, of market failure from the allocation point of view [31], defined as "the failure of a more or less idealized system of price-market institutions to sustain 'desirable' activities or to stop 'undesirable' activities"; here, activities include both consumption and production [274], as first recognized by Pigou in terms of welfare economics [142]. While market failure is ascribed to externalities and collective consumption [275], Randall [276] and Cornes et al. [277] (p. 4), based on the similarity of water to a public good, trace water market failure to non-exclusiveness and non-rivalry which leads to Hardin's 'tragedy of the commons' [278]. An initial view of water market failure was offered by Eckstein [279], where the main causes are pointed out:

1. Increasing returns-to-scale on the production side in water projects lead to the creation of natural monopolies due to large economies of scale.

2. Externalities caused by the physical interdependence of production processes from both quantity and duality, e.g., the spatial case of upstream-downstream uses and the temporal one due to the existence of different seasonal stored water releases, the common-pool impact on ground water and pollution.

3. While classical models are based on income distribution being optimal, water development in many countries aims at correcting income maldistributions, giving more importance to its Keynesian aspect.

4. The assumption of marginality associated with benefit measurements is violated if the market is an oligopoly or, in the case of the government being the single owner/custodian, a monopoly. 
However these have been found to be manageable, e.g., oligopoly/monopoly pricing can be managed by dynamic Ramsey pricing [280], and externalities can be internalized [281].

Moreover, Grafton [282] claims that the traditional focus on supply-based 'solutions' to water scarcity and investing only in water supply infrastructure is an insufficient response to the demand- and supply-side causes of water scarcity. He suggests that wider policy measures are needed such as demand-based water conservation measures leading to water pricing as well as the evaluation of water values across alternative uses to identify and resolve water misallocations [283].

A second viewpoint suggests that "decisions on the optimum use of water and the allocation to different potential uses should be taken on the basis of socio-economic tradeoff analysis that is independent of the ability to pay" [284]; the view expressed is that the government acting as a custodian, in the case where infrastructure problems do not exist or their resolution is currently impossible, must intercede at the consumption source, agriculture or industry, in order to safeguard water sustainability by curtailing overconsumption. In effect it counteracts regular demand and supply rules in relation to water demand management (WDM), as seen initially by Frederick [285] and defined by Winpenny as "(a) policy that stresses making better use of existing supplies, rather than developing new ones" [286]. This can be carried out directly either via 'command and control' or via fiat by setting standards and regulations or, alternatively, via market-based incentive taxation policies by imposing Pigouvian taxes or via informative persuasive strategies. Pigouvian taxes are the imposition of "appropriate rates of tax on resources employed in uses that tend to be pushed too far and employing the proceeds to provide bounties, at "appropriate rates, on uses of the opposite class" [287] (p. 99); they connect in essence to the external effects to consumption, an aspect which was seen later by Meade [288], Tintner [289] and Reder [290]. Pigouvian taxes are contrary to Musgrave's dictum that "taxes should be distributed so as to minimize the total sacrifice involved ... achieved by equating the marginal sacrifices of all taxpayers" [291] (p. 90). The shortcomings of Pigouvian taxes are numerous, starting with Pigou's own opinion "It must be confessed, however, that we seldom know enough to decide in what fields and to what extent the State, on account of [the gaps between private and public costs] could interfere with individual choice" [292]. In the case of pollution and pre-existing distortionary taxes, the optimal pollution tax typically lies below the Pigouvian tax, which fully internalizes the marginal social damage from pollution [293]. However, the success of a Pigouvian intervention lies on the presumption that the Diamond-Mirrlees efficiency conditions apply [294], and on the production efficiency presumably assured by the imposition of a Pigouvian corrective tax which is too restrictive [295], leading to complications whose correction is beyond the application of corrective taxation, as seen in [296]. Sandmo [297] points out that the framework is in partial equilibrium and the benefits accrued are not clear; the second best problems are not taken into account and distributional aspects of optimal taxes are ignored. Buchanan [298] also supports the point of view that if the externality-generating commodity is produced by a monopolist, which in the case of water and the custodian government is true, the Pigouvian tax may reduce efficiency. The 2005 Millennium Assessment favors the use of market instruments in reduction of the demand imposed on ecosystem services [299].

According to Musgrave [291] and Shoup [300] (double counting argument) whether water is free or priced the rate of economic growth and the GDP remain the same.

Support to the market solution can be lent through usufractory water rights trading [301], an easing of which is a solution suggested for water scarcity in the important Colorado River Basin in the western U.S. (which produces $50 \%$ of agricultural products in the U.S.) for the short-term [302], while for the long-term an interstate water market for the basin has been proposed [303]. In this case, the participation of the Federal Government will be funding and oversight of existing facilities and programs, Indian water rights settlements, plans for new and augmented water storage, conveyance and drought contingency plan implementation and future basin agreements [304], a stance that supports a market solution [305]. 
Regarding the second point of view, irrigation taxes were considered in Australia [306]. the imposition of Pigouvian taxes to control irrigation-induced soil degradation was considered in [307] by balancing production vs. degradation costs, by accepting that water for irrigation is usually a common pool resource where water pricing could recover costs and indicate scarcity in the long run, but idoes not seem feasible in the short run for irrigation water reallocation [308]. Mediterranean countries, such as France, Portugal, Italy and Spain have implemented different tax systems on agricultural water abstractions to recover the costs of the regulation, storage and management of basin-level water services with various levels of cost recovery in accordance with the provision by the Water Framework Directive. France, Portugal and Italy have implemented an abstraction tax applied to any water source (surface and groundwater) as an instrument to induce water-saving and internalize environmental and resource costs in the irrigation sector [309]. A practical example is the Neste System of the Compagnie d'Aménagement des Côteaux de Gascogne (CACG) in France, where the charges in $€ / \mathrm{m}^{3}$ are for irrigation (raw water available in the river) $0.015 €$, for irrigation (pressurized raw water brought to the field) $0.15 €$ and for industrial raw water $0.024 €$ [310], where the dominant Pigouvian taxes are the price charged for irrigation raw water and the one for industrial raw water which is $60 \%$ over the one for irrigation. However, as it is a sensitive political issue in the EU, where large, collective irrigation networks are managed by public bodies, the price of water to farmers rarely reflects its full resource and environmental cost [311]. This view is also supported by McNeill [312].

Also, in the case of the U.S., where the eastern part has a riparian framework and the western part operates under the prior appropriation doctrine [313], the Federal Government has the ability to regulate water use directly through the Commerce Clause and the Property Clause of the Constitution or indirectly through the Taxation Clause of the Constitution [314], and a suggestion is that a Pigouvian tax should be imposed [315].

\section{Conclusions}

In terms of water's aspect of being an economic and social good, some parts of economic theory are manifestly covered. Going deeper, however, there is an ongoing controversy over whether water should be considered a market good or a good requiring special consideration which necessitates the formal declaration of the primacy of government as a custodian or perhaps going all the way to water being declared a state-owned good. This last point of view is bound to be reinforced at national level in the case of heavy water stress and beyond that in the case of water scarcity. In reality, the dual nature of water, that of being an economic and a social good, leads formally to the establishment of a balance between these opposing views. Moreover, the property of water being a type of 'special' economic entity due to its critical physical and economic role, in addition to being an economic and social good, has not been introduced in terms of theory in any applicable way, probably because this is a matter that can be initially handled at national level, which could subsequently lead to a global position as a result of a consensus.

The public trust doctrine, being applicable as yet to very few countries, has the advantage of enforcing water sustainability but is deemed ineffective and a direct threat to water rights while its application is not mandatory but is based on judicial decisions. In practice, it reinforces the aforementioned controversy in the form of water being a market good versus a priced/non-priced public good. The balance mentioned above is examined in the proposition that water is a good that requires state supervision/regulation. This is less restrictive than public trust stewardship while the 'water market' alternative is shown to be in a nascent state in terms of volume traded although there are indications that it may grow in the future. Water is shown in this paper to be a heavily regulated commodity, where the water charge paid by the user is equivalent to a tariff, and the imposition of a Pigouvian tax is examined for shortfall and water conservation technologies subsidization, storage expansion or the opportunity cost of water used in place of a general tax.

Water, being a natural resource, is shown to be governed in terms of scarcity according to Malthusian theory, which can be reconciled to Hotelling's theory and is supported by 
Robinson, under the Boserup-Kaldor condition that technological innovation should be taken into account. The Borlaug hypothesis is shown to be correct at a global scale but incorrect at smaller country scales. 'Need' is examined from the theoretical point of view as well as from the points of view of Adam Smith and Winpenny and is divided into prescriptive and motivational need as scarcity is shown to be demand driven, part of which is need, while scarcity's role as a 'bottleneck' to growth is shown to be correct, since water is a congestible nonexcludable good.

Agricultural water management changes is examined in terms of definitions and climate causality, especially for irrigated agriculture. Different management strategic changes are considered in terms of allocation on the basis of water mobility in four scenarios, while adaptation needs are examined. The qualifications of the agent of change are analysed; the common pool resource management case is considered as well as Ostrom's action-arena and the interaction space-based Forrester's system dynamics modelling (SDM). A method of management correction is shown, moving down the scaling axis from global to local.

As a cumulative conclusion, the country level economic properties of water are shown to be different in some important aspects from the global ones. This corresponds to the physical fact that water at global level is a closed physical system but at country level it is an open one.

Author Contributions: Conceptualization, K.Z., D.Z. and D.P.; methodology, K.Z., D.Z. and D.P.; validation, K.Z. and D.P.; formal analysis, K.Z., D.Z. and D.P.; investigation, K.Z., D.Z. and D.P.; resources, K.Z., D.Z. and D.P.; data curation, K.Z. and D.P.; writing-original draft preparation, K.Z. and D.P.; writing-review and editing, K.Z. and D.P.; visualization, K.Z. and D.P.; supervision, D.P. All authors have read and agreed to the published version of the manuscript.

Funding: This research received no external funding.

Conflicts of Interest: The authors declare no conflict of interest.

\section{References}

1. Seckler, D.; Amarasinghe, U.; Molden, D.; de Silva, R.; Barker, R. World Water Demand and Supply, 1990 to 2025: Scenarios and Issues; International Water Management Institute: Colombo, Sri Lanka, 1998.

2. FAO. Understanding Water Scarcity; FAO: Rome, Italy, 2020. Available online: https://www.fao.org/resources/infographics/infog raphics-details/en/c/218939/ (accessed on 25 December 2020).

3. Alcamo, J.M.; Vörösmarty, C.J.; Naiman, R.J.; Lettenmaier, D.P.; Pahl-Wostl, C. A grand challenge for freshwater research: Understanding the global water system. Environ. Res. Lett. 2008, 3, 010202. [CrossRef]

4. Ahopelto, L.; Veijalainen, N.; Guillaume, J.; Keskinen, M.; Marttunen, M.; Varis, O. Can There be Water Scarcity with Abundance of Water? Analyzing Water Stress during a Severe Drought in Finland. Sustainability 2019, 11, 1548. [CrossRef]

5. Nairizi, S. Irrigated Agriculture Development under Drought and Water Scarcity; International Commission on Irrigation and Drainage (ICID): New Delhi, India, 2017. Available online: https:/ / www.icid.org/drought_pub2017.pdf (accessed on 17 July 2020).

6. Seckler, D.; Barker, R.; Amarasinghe, U. Water scarcity in the twenty-first century. Int. J. Water Resour. Dev. 1999, 15, 29-42. [CrossRef]

7. Molden, D. Water for Food, Water for Life: A Comprehensive Assessment of Water Management in Agriculture; Earthscan/International Water Management Institute: Colombo, Sri Lanka, 2007.

8. OECD. Pricing of Water Services; OECD: Paris, France, 1987.

9. ICWE. The Dublin Statement on Water and Sustainable Development. In Proceedings of the ICWE (International Conference on Water and the Environment), Dublin, Ireland, 26-31 January 1992; p. 55.

10. United Nations. Protection of the Quality and Supply of Freshwater Resources: Application of Integrated Approaches to the Development, Management and Use of Water Resources. In Proceedings of the United Nations Conference on Environment \& Development Agenda 21, Rio de Janerio, Brazil, 3-14 June 1992; pp. $196-225$.

11. Ponce, R.; Bosello, F.; Giupponi, C. Integrating Water Resources into Computable General Equilibrium Models-A Survey; Climate Change and Sustainable Development Series; Fondazione Eni Enrico Mattei (FEEM): Milano, Italy, 2012.

12. Plassmann, F. The advantage of avoiding the Armington assumption in multi-region models. Reg. Sci. Urban Econ. 2005, 35, 777-794. [CrossRef]

13. Allan, J.A. "Virtual water": A long term solution for water short Middle Eastern economies? In Proceedings of the British Association Festival of Science, Leeds, UK, 9 September 1997; pp. 24-29. [CrossRef]

14. Randall, A. Property Entitlements and Pricing for a Maturing Water Economy. Aust. J. Agric. Econ. 1981, 25, 195-220. [CrossRef]

15. Booker, J.F. Implications of Water Scarcity for Water Productivity and Farm Labor. Water 2020, 12, 308. [CrossRef] 
16. Jägermeyr, J.; Gerten, D.; Heinke, J.; Schaphoff, S.; Kummu, M.; Lucht, W. Water savings potentials of irrigation systems: Global simulation of processes and linkages. Hydrol. Earth Syst. Sci. 2015, 19, 3073-3091. [CrossRef]

17. Guarino, A.S. The Economic Implications of Global Water Scarcity. Res. Econ. Manag. 2017, 2, 51. [CrossRef]

18. Liu, J.; Hertel, T.W.; Taheripour, F.; Zhu, T. Water Scarcity and International Agricultural Trade. In Proceedings of the Agricultural \& Applied Economics Association's 2013 AAEA \& CAES Joint Annual Meeting, Washington, DC, USA, 4-6 August 2013; pp. 1-17. [CrossRef]

19. Zisopoulou, K.; Panagoulia, D. An In-Depth Analysis of Physical Blue and Green Water Scarcity in Agriculture in Terms of Causes and Events and Perceived Amenability to Economic Interpretation. Water 2021, 13, 1693. [CrossRef]

20. Rind, D. Complexity and climate. Science 1999, 284, 105-107. [CrossRef]

21. Arthur, W.B. Complexity and the Economy. Science 1999, 284, 107-109. [CrossRef]

22. Forrester, J.W. Lessons from system dynamics modeling. Syst. Dyn. Rev. 1987, 3, 136-149. [CrossRef]

23. Sood, A.; Prathapar, S.; Smakhtin, V. Green and Blue Water. In Key Concepts in Water Resource Management: A Review and Critical Evaluation; Lautze, J., Ed.; Routledge: Milton Park, UK, 2014; ISBN 9780415711739.

24. Lazarovitch, N.; Vanderborght, J.; Jin, Y. The Root Zone: Soil Physics and Beyond. Vadose Zo. J. 2018, 17, 1-7. [CrossRef]

25. Falkenmark, M. Land-water linkages: A synopsis. Land and Water Integration and River Basin Management. FAO L. Water Bull. 1995, 1, 15-16.

26. Falkenmark, M.; Rockström, J. The new blue and green water paradigm: Breaking new ground for water resources planning and management. J. Water Resour. Plan. Manag. 2006, 132, 129-132. [CrossRef]

27. Mohtar, R.H.; Assi, A.T.; Daher, B.T. Bridging the Water and Food Gap: The Role of the Water-Energy-Food Nexus; United Nations University Institute for Integrated Management of Material Fluxes and of Resources: Dresden, Germany, 2015; pp. 1-31.

28. Wu, H.T. Research on Assessment and Management of Green Water. China Popul. Resour. Environ. 2008, $18,61-67$.

29. Robbins, L. An Essay on the Nature and Significance of Economic Science; Macmillan and Co.: London, UK, 1932.

30. Winpenny, J. Managing Water as an Economic Resource; Routledge: London, UK, 1994.

31. Perry, C.; Rock, M.; Seckler, D. Water as an Economic Good: A Solution, or a Problem? International Irrigation Management Institute: Colombo, Sri Lanka, 1997.

32. Faber, M.; Manstetten, R.; Müller, G. Interdisziplinäre Umweltforschung aus ökonomischer Sicht. Naturwissenschaften 1994, 81, 193-199. [CrossRef]

33. Baumgärtner, S.; Becker, C.; Faber, M.; Manstetten, R. Relative and absolute scarcity of nature. Assessing the roles of economics and ecology for biodiversity conservation. Ecol. Econ. 2006, 59, 487-498. [CrossRef]

34. Sahu, N.C.; Nayak, B. Niche diversification in environmental/ecological economics. Ecol. Econ. 1994, 11, 9-19. [CrossRef]

35. Debreu, G. Theory of Value: An Axiomatic Analysis of Economic Equibrium; Monographs: London, UK, 1971.

36. Turner, K.; Georgiou, S.; Clark, R.; Brouwer, R.; Burke, J. Economic Valuation of Water Resources in Agriculture: From the Sectoral to a Functional Perspective of Natural Resource Management; FAO Water Reports: Rome, Italy, 2004.

37. De Bono, E. When opportunity knocks. Manag. Today 1978, 18, 102-105.

38. Hulbert, B.; Brown, R.B.; Adams, S. Towards an understanding of 'opportunity'. Mark. Educ. Rev. 1997, 7, 67-73. [CrossRef]

39. Zisopoulou, K.; Panagoulia, D. Solar Power: A new mathematical definition and theoretical proof it is a Green Public Good. Green Financ. 2019, 1, 312-327. [CrossRef]

40. Koutsoyiannis, D. Revisiting the global hydrological cycle: Is it intensifying? Hydrol. Earth Syst. Sci. 2020, 24, 3899-3932. [CrossRef]

41. Yamamori, T. The concept of need in Adam Smith. Cambridge J. Econ. 2016, 41, 327-347. [CrossRef]

42. Smith, A. The Wealth of Nations (1776); CreateSpace Independent Publishing Platform: Scotts Valley, CA, USA, 2018.

43. Leagans, J.P. Concept of Needs. J. Ext. 1964, 2, 89-96.

44. Beatty, P.T. The concept of need: Proposal for a working definition. J. Community Dev. Soc. 1981, 12, 39-46. [CrossRef]

45. Samuelson, P.A. Economics: An Introductory Analysis; McGraw-Hill Book Company, Inc.: New York, NY, USA, 1955.

46. Thaler, R. Toward a positive theory of consumer choice. J. Econ. Behav. Organ. 1980, 1, 39-60. [CrossRef]

47. Kahneman, D.; Thaler, R.H. Anomalies: Utility maximization and experienced utility. J. Econ. Perspect. 2006, 20, 221-234. [CrossRef]

48. WHO/SEARO. Minimum Water Quantity Needed for Domestic Uses. 2005. Available online: https://ec.europa.eu/echo/files/e valuation/watsan2005/annex_files/WHO/WHO5\%20-\%20Minimum\%20water\%20quantity\%20needed\%20for\%20domestic \%20use.pdf (accessed on 18 May 2020).

49. Hussien, W.A.; Memon, F.A. Assessing and Modelling the Influence of Household Characteristics on Per Capita Water Consumption Content courtesy of Springer Nature, terms of use apply. Rights reserved. Water Resour. Manag. 2016, 30, 2931-2955. [CrossRef]

50. De Buck, E.; Borra, V.; De Weerdt, E.; Veegaete, A. Vande A Systematic Review of the Amount of Water per Person per Day Needed to Prevent Morbidity and Mortality in (Post-) Disaster Settings. PLoS ONE 2015, 10, e0126395. [CrossRef]

51. Gleick, P.H.; Iwra, M. Basic Water Requirements. Water Int. 1996, 21, 83-92. [CrossRef]

52. Varian, H.R. Microeconomic Analysis, 3rd ed.; W.W. Norton \& Co: New York, NY, USA, 1992; ISBN 0393957357.

53. U.N. United Nations Sustainable Development Goals, Goal 2: Zero Hunger; U.N.: New York, NY, USA, 2019.

54. FAO. Energy-Smart Food at FAO: An Overview; FAO: Rome, Italy, 2012.

55. Malmberg, B. Demography and the Development Potential of Sub-Saharan Africa; Nordiska Afrikainstitutet: Uppsala, Sweden, 2008.

56. Scott, J. A Dictionary of Sociology; Oxford University Press: Oxford, UK, 2014. 
57. Samuelson, P.A. The Pure Theory of Public Expenditure. Rev. Econ. Stat. 1954, 36, 387-389. [CrossRef]

58. Mishan, E.J. An Introduction to Normative Economics; Oxford University Press: Oxford, UK, 1981.

59. Aylward, B. Water, Public Goods and Market Failure: ANNEX Final Report on Political Economy of Water Markets; AMP InsightsEcosystem Economics: Portland, ME, USA, 2016. Available online: http://www.ampinsights.com/rock-report (accessed on 11 December 2019).

60. White, C. Understanding Water Markets: Public vs. Private Goods. Global Water Forum. 2015. Available online: https: //globalwaterforum.org/2015/04/27/understanding-water-markets-public-vs-private-goods/ (accessed on 24 March 2021).

61. Apesteguia, J.; Maier-Rigaud, F.P. The role of rivalry: Public goods versus common-pool resources. J. Conflict Resolut. 2006, 50, 646-663. [CrossRef]

62. Black, J.; Hashimzade, N.; Myles, G. Impure Public Good. In A Dictionary of Economics; Oxford University Press: Oxford, UK, 2009.

63. Sandler, T. Assessing the Optimal Provision of Public Goods: In Search of the Holy Grail. In Providing Global Public Goods; Kaul, I., Conceição, P., Goulven, K.L., Mendoza, R.U., Eds.; Oxford University Press: Oxford, UK, 2003. [CrossRef]

64. Kaul, I.; Mendoza, R.U. Advancing the Concept of Public Goods. In Providing Global Public Goods; Kaul, I., Conceição, P., Goulven, K.L., Mendoza, R.U., Eds.; Oxford University Press: Oxford, UK, 2003.

65. Mor Barak, M.E. The Practice and Science of Social Good: Emerging Paths to Positive Social Impact. Res. Soc. Work Pract. 2020, 30, 139-150. [CrossRef]

66. Day, D. Water as a Social Good. Aust. J. Environ. Manag. 1996, 3, 26-41. [CrossRef]

67. Loehman, E.; Dinar, A. Cooperative Technology Solutions to Externality Problems: The Case of Irrigation Water; University of California, Davis, Department of Agricultural and Resource Economics: Davis, CA, USA, 1992.

68. Bohm, P. Social Efficiency: A Concise Introduction to Welfare Economics, 2nd ed.; Macmillan Education Ltd.: London, UK, 1987.

69. Sukharev, O.S. Institutes of Social Development and their Efficiency Estimation. Montenegrin J. Econ. 2012, 8, 125-150.

70. Hurwicz, L. Inventing New Institutions: The Design Perspective. Am. J. Agric. Econ. 1987, 69, 395-402. [CrossRef]

71. FAO. Method Used to Compute Water Resources by Country; FAO: Rome, Italy, 2000. Available online: http://www.fao.org/3/y447 3e/y4473e07.htm (accessed on 20 September 2021).

72. Rogers, P.; Bhatia, R.; Huber, A. Water as a an Economic Good: How to Put the Principle into Practice; Global Water Partnership: Stockholm, Sweden, 1998

73. Hussein, M.A. Impacts of Water Scarcity on the Social Welfare of Citizens in the Middle East. In Pathways to Sustainability Vol 1; Middle East Institute: Washington, DC, USA, 2011; pp. 20-24.

74. UNRISD. Transformative Social Policy Lessons from UNRISD Research; UNRISD: Geneva, Switzerland, 2005.

75. Perlo-Freeman, S.; Webber, D.J. Basic Needs, Government Debt and Economic Growth. World Econ. 2009, 32, 965-994. [CrossRef]

76. Boulanger, P.; Dudu, H.; Ferrari, E.; Causapé, A.J.M.; Balié, J.; Battaglia, L. JRC Science for Policy Report: Policy Options to Support the Agriculture Sector Growth and Transformation Strategy in Kenya: A CGE analysis; EU Publication: Brussels, Belgium, 2018. [CrossRef]

77. Chang, H.-J. Resthinking Public Policy in Agriculture: Lessons from Distant and Recent History; FAO: Rome, Italy, 2009.

78. Leamer, E.E. The Heckser-Olin Model in Theory and Practice; Princeton Studies in International Finance: Princeton, NJ, USA, 1995.

79. Carr, J.A.; D'Odorico, P.; Laio, F.; Ridolfi, L. On the temporal variability of the virtual water network. Geophys. Res. Lett. 2012, 39, 1-7. [CrossRef]

80. FAO. The State of Agricultural Commodity Markets and Sustainable Development: Global Value Chains, Smallholder Farmers and Digital Innovations; FAO: Rome, Italy, 2020.

81. Boulding, K.E. Economic Analysis: Volume II: Microeconomics; Harper and Row: New York, NY, USA, 1966; Volume II.

82. Vernon, R. International Investment and International Trade in the Product Cycle. Q. J. Econ. 1966, 80, 190-207. [CrossRef]

83. Khan, N.; Ray, R.L.; Sargani, G.R.; Ihtisham, M.; Khayyam, M.; Ismail, S. Current progress and future prospects of agriculture technology: Gateway to sustainable agriculture. Sustainability 2021, 13, 4883. [CrossRef]

84. World Bank. World Bank Open Data. 2021. Available online: https:/ / data.worldbank.org/ (accessed on 15 November 2021).

85. Frierson, D.M.W.; Hwang, Y.T.; Fučkar, N.S.; Seager, R.; Kang, S.M.; Donohoe, A.; Maroon, E.A.; Liu, X.; Battisti, D.S. Contribution of ocean overturning circulation to tropical rainfall peak in the Northern Hemisphere. Nat. Geosci. 2013, 6, 940-944. [CrossRef]

86. Weaver, A.J.; Sedláček, J.; Eby, M.; Alexander, K.; Crespin, E.; Fichefet, T.; Philippon-Berthier, G.; Joos, F.; Kawamiy, M.; Matsumoto, K.; et al. Stability of the Atlantic meridional overturning circulation: A model intercomparison. Geophys. Res. Lett. 2012, 39, 1-7. [CrossRef]

87. Walsh, J.E. Melting ice: What is happening to Arctic sea ice, and what does it mean for us? Oceanography 2013, 26, 171-181. [CrossRef]

88. Sayan, S. H-O for H2O: Can the Heckscher-Ohlin Framework Explain the Role of Free Trade in Distributing Scarce Water Resources Around the Middle East? Rev. Middle East Econ. Financ. 2009, 1, 21-36. [CrossRef]

89. Porter, M. The Competitive Advantage of Nations. Harv. Bus. Rev. 1990, 21. Available online: https://hbr.org/1990/03/the-co mpetitive-advantage-of-nations (accessed on 16 November 2021).

90. Peteraf, M.A. The Cornerstones of Competitive Advantage: A Resource-Based View. Strateg. Manag. J. 1993, 14, 179-191. [CrossRef]

91. Peteraf, M.A.; Bergen, M.E. Scanning dynamic competitive landscapes: A market-based and resource-based framework. Strateg. Manag. J. 2003, 24, 1027-1041. [CrossRef]

92. Hamilton, K.; Hepburn, C. Wealth. Oxford Rev. Econ. Policy 2014, 30, 1-20. [CrossRef]

93. Savenije, H.H.G. Why water is not an ordinary economic good, or why the girl is special. Phys. Chem. Earth 2002, 27, 741-744. [CrossRef]

94. Seyam, I.M.; Hoekstra, A.Y. The Water Value-Flow Concept. Phys. Chem. Earth 2003, 28, 175-182. [CrossRef] 
95. Bjornlund, H.; Mckay, J.M. Aspects of water markets for developing countries: Experiences from Australia, Chile and the US Environ. Dev. Econ. 2002, 7, 767-793. [CrossRef]

96. Debaere, P.; Richter, B.D.; Davis, K.F.; Duvall, M.S.; Gephart, J.A.; O’Bannon, C.E.; Pelnik, C.; Powell, E.M.; Smith, T.W. Water markets as a response to scarcity. Water Policy 2014, 16, 625-649. [CrossRef]

97. Booker, J.F.; Howitt, R.E.; Michelsen, A.M.; Young, R.A. Economics and the modeling of water resources and policies. Nat. Resour. Model. 2012, 25, 168-218. [CrossRef]

98. Schwabe, K.; Nemati, M.; Landry, C.; Zimmerman, G. Water markets in the Western United States: Trends and opportunities. Water 2020, 12, 233. [CrossRef]

99. Tisdell, J.G. The environmental impact of water markets: An Australian case-study. J. Environ. Manag. 2001, 62, 113-120. [CrossRef]

100. Endo, T.; Kakinuma, K.; Yoshikawa, S.; Kanae, S. Are water markets globally applicable? Environ. Res. Lett. 2018, 13, 034032. [CrossRef]

101. Guzmán, D.A.; Mohor, G.S.; Mendiondo, E.M. Multi-year index-based insurance for adapting water utility companies to hydrological drought: Case study of a water supply system of the Sao Paulo Metropolitan Region, Brazil. Water 2020, 12, 2954. [CrossRef]

102. Bauer, C.J. Results of Chilean water markets: Empirical research since 1990. Water Resour. Res. 2004, 40, 1-11. [CrossRef]

103. Holden, P.; Thobani, M. Tradable Water Rights: A Property Rights Approach to Resolving Water Shortages and Promoting Investment; World Bank: Washington, DC, USA, 1996.

104. Mateo-Sagasta, J.; Zadeh, S.M.; Turral, H. Water Pollution from Agriculture: A Global Review; FAO: Rome, Italy, 2017. Available online: http:/ / www.fao.org/3/a-i7754e.pdf (accessed on 11 December 2019).

105. Donoso, G. The evolution of water markets in Chile. In Water Trading and Global Water Scarcity: International Experiences; Maestu, J., Ed.; Routledge: London, UK, 2012; pp. 111-129.

106. Pfister, S.; Koehler, A.; Hellweg, S. Assessing the Environmental Impacts of Freshwater Consumption in LCA. Environ. Sci. Technol. 2009, 43, 4098-4104. [CrossRef]

107. Westall, F.; Brack, A. The Importance of Water for Life. Sp. Sci. Rev. 2018, 214, 1-23. [CrossRef]

108. Falkenmark, M. Water resilience and human life support-Global outlook for the next half century. Int. J. Water Resour. Dev. 2020, 36, 377-396. [CrossRef]

109. U.N. U.N. Report of the United Nations Conference on Environment and Development. In United Nations Conference on Environment and Development Rio de Janeiro; U.N.: New York, NY, USA, 1992; Volume 1, p. 492.

110. Parliament of Kenya. THE WATER ACT, 2016; The Government of Kenya: Nairobi, Kenya, 2016.

111. Ferris, L. The Public Trust Doctrine and Liability for Historic Water Pollution in South Africa. Law Environ. Dev. J. 2012, 8, 1-18.

112. Frank, R.M. The Public Trust Doctrine: Assessing Its Recent Past \& Charting Its Future. US Davis Law Rev. 2012, 45, 665.

113. Sax, J.L. The Public Trust Doctrine in Natural Resource Law: Effective Judicial Intervention. Michigan Law Rev. T 1970, 68, 475-531. [CrossRef]

114. Blumm, M.; Wood, M.C. The Public Trust Doctrine in Environmental and Natural Resources Law; Carolina Academic Press: Durham, NC, USA, 2013.

115. Weiss, E.B. In Fairness to Future Generations: International Law, Common Patrimony, and Intergenerational Equity (Innovation in International Law); Transnational Pub Inc.: Ardsley, NY, USA, 1989.

116. E.U. E.U. Directive 2000/60/EC of the European Parliament and of the Council; EU: Brussels, Belgium, 2000. Available online: https:/ / eur-lex.europa.eu/legal-content/EN/TXT/HTML/?uri=CELEX:32000L0060\&rid=2 (accessed on 25 May 2020).

117. EEAC Working Group on Fresh Water Affairs. The EU Water Framework Directive-Results to Date and Outlook for the Future; EU: Brussels, Belgium, 2018.

118. Sagarin, R.D.; Turnipseed, M. The public trust doctrine: Where ecology meets natural resources management. Annu. Rev. Environ. Resour. 2012, 37, 473-496. [CrossRef]

119. Kameri-Mbote, P. Public Trust doctrine in environmental law. Law Environ. Dev. J. 2007, 3, 11.

120. Chong, H.; Sunding, D. Water markets and trading. Annu. Rev. Environ. Resour. 2006, 31, 239-264. [CrossRef]

121. Richardson, J. Who Owns the Water: A Summary of Existing Water Rights Laws; Water Systems Council: Washington, DC, USA, 2016.

122. Smith, M.D., Jr. A Blast From The Past: The Public Trust Doctrine. Environ. Law 2016, 46, 461-480.

123. Zellmer, S.; Harder, J. Unbundling Property in Water. Ala. L. Rev. 2007, 59, 679.

124. Lazarus, R.J. Changing conceptions of property and sovereignty in natural resources: Questioning the public trust doctrine. Iowa Law Rev. 1986, 71, 631-716.

125. Babcock, H.M. The Public Trust Doctrine: What a Tall Tale They Tell. S. C. Law Rev. 2009, 61, 393-414.

126. Araiza, W.D. Democracy, distrust, and the public trust: Process-based constitutional theory, the public trust doctrine, and the search for a substantive environmental value. UCLA Law Rev. 1997, 45, 385. [CrossRef]

127. Regalia, J. A New Water Law Vista: Rooting the Public Trust Doctrine in the Courts. Kentucky Law J. 2019, 108, 45. [CrossRef]

128. Turnipseed, M.; Roady, S.E.; Sagarin, R.; Crowder, L.B. Silver anniversary of the united states' exclusive economic zone: Twentyfive years of ocean use and abuse, and the possibility of a blue water public trust doctrine. Ecol. Law Q. 2009, 36, 1-70. [CrossRef]

129. Chambers, R. Irrigation against rural poverty. In National Seminar on Water Management_-The Key to Developing Agriculture; Kanwar, J.S., Ed.; Agricole Publishing Academy: New Delhi, India, 1988.

130. Zilberman, D.; Schoengold, K. The Use of Pricing and Markets for Water Allocation. Can. Water Resour. J. 2005, 30, 47-54. [CrossRef]

131. Pérard, E. Water supply: Public or private? An approach based on cost of funds, transaction costs, efficiency and political costs. Policy Soc. 2009, 27, 193-219. [CrossRef] 
132. Thompson, B.H. Water as a public commodity. Marquette Law Rev. 2011, 95, 17-52.

133. Plessis, W.D.; Kotze, L.J. Absolving historical polluters from liability through restrictive judicial interpretation: Some thoughts on Bareki NO v Gencor Ltd. Stellenbosch Law Rev. 2007, 18, 161-193.

134. Morgan, A.J.; Orr, S. The value of water: A Framework for Understanding Water Valuation, Risk and Stewardship. 2015. Available online: https://d2ouvy59p0dg6k.cloudfront.net/downloads/the_value_of_water_discussion_draft_final_august_20 15.pdf (accessed on 16 November 2021).

135. Young, R.A.; Haveman, R.H. Economics of Water Resources: A Survey. In Handbook of Natural Resource and Energy Economics; Kneese, A.V., Sweeney, J.L., Eds.; North Holland: Amsterdam, The Netherlands, 1985; Volume II, pp. 465-529. Available online: http:/ / ron-griffin.tamu.edu/x677/readings/younghaveman1985.pdf (accessed on 13 July 2020).

136. Young, R.A. Measuring Economic Benefits for Water Investments and Policies; World Bank: Washington, DC, USA, 1996.

137. Easter, W.K.; Becker, N.; Tsur, Y. Economic mechanisms for managing water resources: Pricing, permits and markets. In Water Resources: Environmental Planning, Management and Development; Biswas, A.K., Ed.; McGraw-Hill: New York, NY, USA, 1997.

138. Dommen, E. New Horizons in Environmental Economics: Fair Principles for Sustainable Development: Essays on Environmental Policy in Developing Countries; Dommen, E., Ed.; Edward Elgar for and on behalf of the United Nations: Brookfield, VT, USA, 1993.

139. OECD. Water Charges in Brazil The Ways Forward; OECD Studies on Water; OECD: Paris, France, 2017. [CrossRef]

140. Monteiro dos Santos, F.A.; Coelho-Junior, M.G.; Chaves Cardoso, J.; Basso, V.M.; de Paula Marques, A.L.; Ribeiro da Silva, E.M. Program outcomes of payments for watershed services in Brazilian Atlantic forest: How to evaluate to improve decision-making and the socio-environmental benefits. Water 2020, 12, 2441. [CrossRef]

141. Molle, F.; Berkoff, J. Water pricing in irrigation: Mapping the debate in the light of experience. In Irrigation Water Pricing: The Gap Between Theory and Practice; Molle, F., Berkoff, J., Eds.; CAB International: Wallingford, UK, 2007; pp. 21-93.

142. Pigou, A.C. The Economis of Welfare, 3rd ed.; Macmillan and Co.: New York, NY, USA, 1929.

143. Hartwick, J.M. Intergenerational Equity and the Investing of Rents from Exhaustible Resources. Am. Econ. Rev. 1977, 67, 972-974.

144. Dasgupta, S.; Mitra, T. Intertem Poral Equity and Hartwick's Rule in an Exhaustible Resource Model; Cornell University: New York, NY, USA, 2002.

145. Von Haldenwang, C. Taxation of Non-Renewable Natural Resources: What are the Key Issues? Deutsches Institut für Entwicklungspolitik (DIE): Bonn, Germany, 2011.

146. Basili, M.; Casaca, P.; Chateauneuf, A.; Franzini, M. Multidimensional Pigou-Dalton Transfers and Social Evaluation Functions. Theory Decis. 2017, 83, 573-590. [CrossRef]

147. Malthus, T. An Essay on the Principle of Population: The 1803 Edition; St. Paul's Church-Yard: London, UK, $1798 ;$ ISBN 9780300177411.

148. Sen, A. Poverty and Famines An Essay on Entitlement and Deprivation; Clarendon Press Oxford: Oxford, UK, 1981; ISBN 0-19-828426-8.

149. Samuelson, P.A.; Nordhaus, W.D. Economics, 19th ed.; McGraw Hill International Edition: New York, NY, USA, 2009; ISBN 9780073511290

150. Mursa, G.C. Scarcity and Population. A Non-Malthusian Point of View. Procedia Soc. Behav. Sci. 2012, 62, 1115-1119. [CrossRef]

151. Ricardo, D. The Principles of Political Economy and Taxation (1817); Dover Publications: New York, NY, USA, 2004.

152. Hall, D.C.; Hall, J.V. Concepts and Measures of Natural Resource with a Summary of Recent Trends. J. Environ. Econ. Manag. 1984, 11, 362-379. [CrossRef]

153. Hotelling, H. The Economics of Exhaustible Resources. J. Polit. Econ. 1931, 39, 137-175. [CrossRef]

154. Heuterkes, E.M. Scarcity, Scarcity Knowledge and the Legitimation of Market-Based Scarcity Indicators; Westfalische WilhelmsUniversitat: Munster, Germany, 2007.

155. Huang, B. An exhaustible resources model in a dynamic input-output framework: A possible reconciliation between Ricardo and Hotelling. J. Econ. Struct. 2018, 7, 8. [CrossRef]

156. Walras, L. Elements of Pure Economics, or The Theory of Social Wealth 1874 (Translated by William Jaffe 1922); Orion Editions: London, UK, 1984; ISBN 978-0879912536.

157. Montani, G. The New Palgrave Dictionary of Economics. In The New Palgrave Dictionary of Economics; Palgrave: London, UK, 2020; pp. 252-253.

158. Montani, G. Scarce Natural Resources and Income Distribution. Metroeconomica 1975, 27, 68-101. [CrossRef]

159. Kummu, M.; Ward, P.J.; De Moel, H.; Varis, O. Is physical water scarcity a new phenomenon? Global assessment of water shortage over the last two millennia. Environ. Res. Lett. 2010, 5, 034006. [CrossRef]

160. Boserup, E. The Conditions of Agricultural Growth: The Economics of Agrarian Change under Population Pressure; George Allen \& Unwin Ltd.: Crows Nest, Australia, 1965; Volume 20. [CrossRef]

161. Alcott, B. Jevons' paradox. Ecol. Econ. 2005, 54, 9-21. [CrossRef]

162. Missemer, A. William Stanley Jevons ' The Coal Question (1865), beyond the rebound effect. Ecol. Econ. 2012, 82, 97-103. [CrossRef]

163. Cohn, A.S.; Mosnier, A.; Havlík, P.; Valin, H.; Herrero, M.; Schmid, E.; O'Haref, M.; Obersteiner, M. Cattle ranching intensification in Brazil can reduce global greenhouse gas emissions by sparing land from deforestation. Proc. Natl. Acad. Sci. USA 2014, 111, 7236-7241. [CrossRef]

164. Hertel, T.W. Economic perspectives on land use change and leakage. Environ. Res. Lett. 2018, 13, 075012. [CrossRef]

165. Hayami, Y.; Ruttan, V.W. Agricultural Development: An International Perspective; RFF Press John Wiley \& Sons: New York, NY, USA, 1985; ISBN 978-0801823480. 
166. Phelps, J.; Carrasco, L.R.; Webb, E.L.; Koh, L.P.; Pascual, U. Agricultural intensification escalates future conservation costs. Proc. Natl. Acad. Sci. USA 2013, 110, 7601-7606. [CrossRef]

167. Garcia, A. The Environmental Impacts of Agricultural Intensification; Standing Panel on Impact Assessment (CGIAR): Rome, Italy, 2020.

168. Barbier, E.B. Economics, Natural-Resource Scarcity and Development Conventional and Alternative Views; Earthscan: London, UK, 1989; ISBN 9781853830242.

169. Daoud, A. Abundance, Scarcity and Sufficiency; University of Göteborg Studies in Sociology: Göteborg, Sweden, 2011.

170. Ohlsson, L.; Turton, A. The Turning of a Screw: Social Resource Scarcity as a Bottle-Neck in Adaptation to Water Scarcity; SOAS Water Study Group: London, UK, 2000.

171. Falkenmark, M. Landscape as life support provider. Water-related limitations. In Population: The Complex Reality; Graham-Smith, F., Ed.; The Royal Society: London, UK, 1994.

172. Falkenmark, M.; Lundqvist, J. Towards water security: Political determination and human adaptation crucial. Nat. Resour. Forum 1998, 22, 37-51. [CrossRef]

173. Vallino, E.; Ridolfi, L.; Laio, F. Measuring economic water scarcity in agriculture: A cross-country empirical investigation. Environ. Sci. Policy 2020, 114, 73-85. [CrossRef]

174. AQUEDUCT. AQUEDUCT Water Risk Atlas. 2021. Available online: https://www.wri.org/applications/aqueduct/water-risk-a tlas $/ \# /$ ?advanced=false\&basemap=hydro\&indicator=w_awr_def_tot_cat\&lat=23.725011735951796\&lng=20.390625000000004 \&mapMode=view\&month=1\&opacity $=0.5 \&$ ponderation $=$ DEF\&predefined $=$ false\&projection=absolute\&scenario $=$ optimistic \&scope=baseline \&threshold \&timeScale $=$ annual $\& y e a r=$ baseline\&zoom $=2$ (accessed on 21 July 2021).

175. World Bank. The World by Income. 2007. Available online: https://datatopics.worldbank.org/world-development-indicators/ the-world-by-income-and-region.html (accessed on 8 September 2020).

176. Kandil, M. Exchange Rate Fluctuations and the Balance of Payments: Channels of Interaction in Developing and Developed Countries. J. Econ. Integr. 2009, 24, 151-174. [CrossRef]

177. Black, S.W. Essays in International Finance: Exchange Policies for Less Developed Countries in a World of Floating Rates; Princeton University Press: Princeton, NY, USA, 1976.

178. Kaimowitz, A.; Angelsen, D. Introduction: The Role of Agricultural Technologies in Tropical Deforestation. In Agricultural Technologies and Tropical Deforestation; Kaimowitz, A., Angelsen, D., Eds.; CABI Publishing: Eggham, UK, 2001; pp. 1-16.

179. Klerkx, L.; Leeuwis, C. Establishment and embedding of innovation brokers at different innovation system levels: Insights from the Dutch agricultural sector. Technol. Forecast. Soc. Change 2009, 76, 849-860. [CrossRef]

180. Howells, J. Intermediation and the role of intermediaries in innovation. Res. Policy 2006, 35, 715-728. [CrossRef]

181. Kimble, C.; Grenier, C.; Goglio-Primard, K. Innovation and knowledge sharing across professional boundaries: Political interplay between boundary objects and brokers. Int. J. Inf. Manag. 2010, 30, 437-444. [CrossRef]

182. Laschewski, L.; Phillipson, J.; Gorton, M. The Facilitation and Formalisation of Small Business Networks: Evidence from the North East of England. Environ. Plan. C 2002, 20, 375-391. [CrossRef]

183. Wolfe, S.; Brooks, D.B. Water scarcity: An alternative view and its implications for policy and capacity building. Nat. Resour. Forum 2003, 27, 99-107. [CrossRef]

184. Amin, M.T.; Han, M. Scope/need of soft path water resource management in developing countries. Water Sci. Technol. Water Supply 2007, 7, 185-192. [CrossRef]

185. Medeiros, P.; Sivapalan, M. From Hard-Path to Soft-Path Solutions: Slow-Fast Dynamics of Human Adaptation to Droughts in a Water Scarce Environment; Taylor \& Francis: Milton Park, Oxfordshire, UK, 2020; Volume 65. [CrossRef]

186. Nechifor, V. Global economic and food security impacts of demand-driven water scarcity. In Proceedings of the 21st Annual Conference on Global Economic Analysis, Cartagena, Colombia, 13-15 June 2018; pp. 1-39. Available online: https: / /www.gtap .agecon.purdue.edu/resources/download/8880.pdf (accessed on 16 November 2021).

187. Cui, R.Y.; Calvin, K.; Clarke, L.; Hejazi, M.; Kim, S.; Kyle, P.; Patel, P.; Turner, S.; Wise, M. Regional responses to future, demand-driven water scarcity. Environ. Res. Lett. 2018, 13, 094006. [CrossRef]

188. Rosengrant, M.W.; Cai, X.; Cline, S.A. World Water and Food to 2025; International Food Policy Research Institute: Washington, DC, USA, 2002.

189. Grafton, R.Q.; Williams, J.; Perry, C.J.; Molle, F.; Ringler, C.; Steduto, P.; Udall, B.; Wheeler, S.A.; Wang, Y.; Garrick, D.; et al. The paradox of irrigation efficiency. Science 2018, 361, 748-750. [CrossRef]

190. Perry, C.; Steduto, P.; Allen, R.G.; Burt, C.M. Increasing productivity in irrigated agriculture: Agronomic constraints and hydrological realities. Agric. Water Manag. 2009, 96, 1517-1524. [CrossRef]

191. Shen, Y.; Oki, T.; Utsumi, N.; Kanae, S.; Hanasaki, N. Projection of future world water resources under SRES scenarios: Water withdrawal. Hydrol. Sci. J. 2008, 53, 11-33. [CrossRef]

192. Rossing, T. Water Scarcity, Climate Change, and the Poor. In Reducing Poverty, Protecting Livelihoods, and Building Assets in a Changing Climate Social Implications of Climate Change for Latin America and the Caribbean; Verner, D., Ed.; World Bank: Washington, DC, USA, 2010; pp. 21-56.

193. Collins, M.; Knutti, R. Long-Term Climate Change: Projections, Commitments and Irreversibility; Cambridge University Press: New York, NY, USA, 2013. 
194. Lund, J.R.; Hanak, E.; Fleenor, W.E.; Bennet, W.A.; Howitt, R.E.; Mount, J.F.; Moyle, P.B. Challenges of managing California's Sacramento-San Joaquin delta. In Proceedings of the World Environmental and Water Resources Congress 2009: Great Rivers, Kansas City, MO, USA, 17-21 May 2009; pp. 2355-2364.

195. Walker, W.R.; Zaccaria, D. Agricultural Water Management Challenges in the Western US; NSF Water Workshop: Cairo, Egypt, $2014 ;$ p. 26.

196. Giordano, M.; Barron, J.; Ünver, O. Water Scarcity and Challenges for Smallholder Agriculture. In Sustainable Food and Agriculture; Academic Press: Cambridge, MA, USA, 2019; pp. 75-94. [CrossRef]

197. Grigg, N.S. Global water infrastructure: State of the art review. Int. J. Water Resour. Dev. 2019, 35, 181-205. [CrossRef]

198. Intelligence Community Assessment. Global Water Security; US Department of State: Washington, DC, USA, 2012.

199. UNESCO WWAP. The United Nations World Water Development Report 2016 Report: Water and Jobs; UNESCO: Paris, France, 2016.

200. Howe, C.W. Symposium on Water Resources Management in a Changing World-The Effects of Water Resource Development on Economic Growth: The Conditions for Success. Nat. Res. J. 1976, 16, 939-955. Available online: https://digitalrepository.unm.ed $\mathrm{u} /$ cgi/viewcontent.cgi? article $=3463 \&$ context $=$ nrj (accessed on 16 November 2021).

201. Barbier, E. Water and Economic Growth. Econ. Rec. 2004, 80,1-16. [CrossRef]

202. Barro, R.J. Government Spending in a Simple Model of Endogeneous Growth. J. Polit. Econ. 1990, 98, S103-S125. [CrossRef]

203. Hertel, T.W.; Liu, J. Implications of Water Scarcity for Economic Growth; OECD Environment Working Papers; OECD: Paris, France, 2016

204. Taheripour, F.; Tyner, W.E.; Sajedinia, E.; Aguiar, A.; Chepeliev, M.; Corong, E.; de Lima, C.Z.; Haqiqi, I. Water in the Balance: The Economic Impacts of Climate Change and Water Scarcity in the Middle East; World Bank Group: Washington, DC, USA, 2020 ; p. 20433.

205. Procházka, P.; Hönig, V.; Maitah, M.; Pljucarská, I.; Kleindienst, J. Evaluation of Water Scarcity in Selected Countries of the Middle East. Water 2018, 10, 1482. [CrossRef]

206. Alrwis, K.N.; Ghanem, A.M.; Alnashwan, O.S.; Al Duwais, A.A.M.; Alaagib, S.A.B.; Aldawdahi, N.M. Measuring the impact of water scarcity on agricultural economic development in Saudi Arabia. Saudi J. Biol. Sci. 2021, 28, 191-195. [CrossRef]

207. OECD. Groundwater Allocation Managing Growing Pressures on Quantity and Quality; OECD Studies on Water; OECD: Paris, France, 2017.

208. Whittington, D.; Sadoff, C.; Allaire, M. The Economic Value of Moving Toward a More Water Secure World; Global Water Partnership Technical Committee (TEC): Stockholm, Sweden, 2013.

209. Dasgupta, P. Human Well-Being and the Natural Environment; Oxford University Press: Oxford, UK, 2004.

210. Sachs, J.D.; Mcarthur, J.W.; Schmidt-traub, G.; Kruk, M.; Bahadur, C.; Faye, M.; Mccord, G.; Faye, M.; Mccord, G. Ending Africa's Poverty Trap Stable. Brookings Pap. Econ. Act. 2004, 1, 117-216. [CrossRef]

211. World Bank Group. High and Dry: Climate Change, Water and the Economy; World Bank Group: Washington, DC, USA, 2016.

212. Blignaut, J.; Van Heerden, J. The impact of water scarcity on economic development initiatives. Water SA 2009, 35, 415-420. [CrossRef]

213. SIWI. Making Water a Part of Economic Development: The Economic Benefi ts of Improved Water Management and Services; United Nations Commission on Sustainable Development: New York, NY, USA, 2004.

214. Zhang, F.; Xue, H.; Wang, H.; Dong, H. Industrial Growth Path under the Restriction of Water Resources in China. Procedia Eng. 2017, 174, 934-940. [CrossRef]

215. Damania, R. The economics of water scarcity and variability. Oxford Rev. Econ. Policy 2020, 36, 24-44. [CrossRef]

216. Gleick, P.H. The human right to water. Water Policy 1999, 5, 487-503.

217. Mintzberg, H. Managing; Berret-Koehler Paublishers, Inc.: San Fransisco, CA, USA, 2009.

218. Naylor, J. Management, 2nd ed.; Pearson Education Limited: Harlow, UK, 2004.

219. Moore, M.H. A Conception of Public Management; Harvard University Working Paper; Harvard University Press: Cambridge, MA, USA, 1983; pp. 1-12.

220. Moore, M.H. Creating Public Value: Strategic Management in Government by Mark H. Moore; Harvard University Press: Cambridge, MA, USA, 1995; p. 416.

221. United States Department of Agriculture. Water Management. Natural Resources Conservation Service. Available online: https://www.nrcs.usda.gov/wps/portal/nrcs/main/national/water/manage/ (accessed on 21 July 2021).

222. Global Water. Agricultural Water Management. Available online: https://www.globalwaters.org/resources/agricultural-watermanagement (accessed on 21 July 2021).

223. Savenije, H.H.G. Lecture Notes: Water Resources Management Concepts and Tools; IHE Delft: Delft, The Netherlands, $1996 ; \mathrm{p} .112$.

224. Savenije, H.H.G.; Hoekstra, A.Y. Water Resources Managment. In Knowledge for Sustainable Development: An Insight into the Encyclopedia of Life Support Systems; UNESCO-Encyclopedia Life Support Systems (UNESCO-EOLSS): Paris, France, 2002; pp. $155-180$.

225. Armstrong, S. Handbook of Human Resource Management Practice, 13th ed.; Kogan Page Limited: London, UK, 2014.

226. Sammut-Bonnici, T. Strategy. In Wiley Encyclopedia of Management Volume 6; Wiley: Chichester, UK, 2015 ; p. 449.

227. Taher, M.; Connor, J.D.; Albiac, J. Efficient water management policies for irrigation adaptation to climate change in Southern Europe. Ecol. Econ. 2015, 120, 226-233. [CrossRef]

228. Ward, F.A.; Hurd, B.H.; Rahmani, T.; Golleho, N. Economic impacts of federal policy responses to drought in the Rio Grande Basin. Water Resour. Res. 2006, 42, 1-13. [CrossRef]

229. Zilberman, D.; Berkley, C.; Dinar, A.; Macdougall, N.; Khanna, M.; Brown, C.; Castillo, F. Individual and Institutional Responses to the Drought: The Case of California Agriculture. J. Contemp. Water Res. Educ. 2002, 121, 17-23.

230. Nechifor, V.; Winning, M. Global economic and food security impacts of demand-driven water scarcity-alternative water management options for a thirsty world. Water 2018, 10, 1442. [CrossRef] 
231. Lorite, I.J.; Soriano, M.A.; Fereres, E. Management trends and responses to water scarcity in an irrigation scheme of Southern Spain. Agric. Water Manag. 2008, 95, 458-468. [CrossRef]

232. Iglesias, A.; Garrote, L. Adaptation strategies for agricultural water management under climate change in Europe. Agric. Water Manag. 2015, 155, 113-124. [CrossRef]

233. Santos, L.; Oweis, T.; Zairi, A. Irrigation management under water scarcity. Agric. Water Manag. 2002, 57, $175-206$.

234. Lunenburg, F.C. Managing Change: The Role of the Change Agent. Int. J. Manag. Bus. Adm. 2010, 13, 1-6.

235. Sarkera, A.; Baldwinb, C.; Rossa, H. Managing groundwater as a common-pool resource: An Australian case study. Water Policy 2009, 11, 598-614. [CrossRef]

236. Ostrom, E. Governing the Commons: The Evolution of Institutions for Collective Action, 29th ed.; Cambridge University Press: New York, NY, USA, 1990.

237. Ostrom, E. An Agenda for the Study of Institutions. Public Choice 1986, 48, 3-25. [CrossRef]

238. Forrester, J.W. Industrial Dynamics-After the First Decade Author. Manag. Sci. 1968, 14, 398-415. [CrossRef]

239. Ostanello, A.; Tsoukiás, A. An explicative model of "public" interorganizational interactions. Eur. J. Oper. Res. 1993, 70, 67-82. [CrossRef]

240. Winz, I.; Brierley, G.; Trowsdale, S. The use of system dynamics simulation in water resources management. Water Resour. Manag. 2009, 23, 1301-1323. [CrossRef]

241. Zarghami, S.A.; Gunawan, I.; Schultmann, F. System Dynamics Modelling Process in Water Sector: A Review of Research Literature. Syst. Res. Behav. Sci. 2018, 35, 776-790. [CrossRef]

242. Kotir, J.H.; Smith, C.; Brown, G.; Marshall, N.; Johnstone, R. A system dynamics simulation model for sustainable water resources management and agricultural development in the Volta River Basin, Ghana. Sci. Total Environ. 2016, 573, 444-457. [CrossRef]

243. Rehan, R.; Knight, M.A.; Haas, C.T.; Unger, A.J.A. Application of system dynamics for developing financially self-sustaining management policies for water and wastewater systems. Water Res. 2011, 45, 4737-4750. [CrossRef]

244. Tidwell, V.C.; Passell, H.D.; Conrad, S.H.; Thomas, R.P. System dynamics modeling for community-based water planning: Application to the Middle Rio Grande. Aquat. Sci. 2004, 66, 357-372. [CrossRef]

245. Liu, H.; Benoit, G.; Liu, T.; Liu, Y.; Guo, H. An integrated system dynamics model developed for managing lake water quality at the watershed scale. J. Environ. Manag. 2015, 155, 11-23. [CrossRef]

246. Sun, Y.; Liu, N.; Shang, J.; Zhang, J. Sustainable utilization of water resources in China: A system dynamics model. J. Clean. Prod. 2017, 142, 613-625. [CrossRef]

247. Pluchinotta, I.; Pagano, A.; Giordano, R.; Tsoukiàs, A. A system dynamics model for supporting decision-makers in irrigation water management. J. Environ. Manag. 2018, 223, 815-824. [CrossRef]

248. Pfeiffer, L.; Lin, C.-Y.C. Does Efficient Irrigation Technology Lead to Reduced Groundwater Extraction? Empirical Evidence. 2010. Available online: https:/ /ageconsearch.umn.edu/search?ln=en\&cc=320 (accessed on 12 March 2020).

249. Wheeler, S.A.; Bark, R.; Loch, A.; Connor, J. Agricultural water management. In Handbook of Water Economics; Dinar, A., Schwabe, K., Eds.; Elgar: Cheltenham, UK, 2015; pp. 71-86.

250. Stacey, R.D. The Science of Complexity: An Alternative Perspective for Strategic Change Processes. Strateg. Manag. J. 1995, 16, 477495. [CrossRef]

251. Heeks, R. Information systems and developing countries: Failure, success, and local improvisations. Inf. Soc. 2002, 18, 101-112. [CrossRef]

252. Heeks, R. Most eGovernment-for-Development Projects Fail: How Can Risks be Reduced? iGovernment Working Paper Series; University of Manchester: Manchester, UK, 2003.

253. Masiero, S. The Origins of Failure: Seeking the Causes of Design-Reality Gaps. Inf. Technol. Dev. 2016, 22, 487-502. [CrossRef]

254. Lessa, L.; Negash, S.; Belachew, M. Steering e-government projects from failure to success: Using design-reality gap analysis as a mid-implementation assessment tool. In International Business: Concepts, Methodologies, Tools, and Applications; IGI Global: Hershey, PA, USA, 2012; pp. 1884-1898.

255. Ferlie, E.; Pettigrew, A.; Ashburner, L.; Fitzgerald, L. The New Public Management in Action; Oxford University Press: Oxford, UK, 1996.

256. Cummings, T.G.; Worley, C.G. Organization Development E Change, 10th ed.; Cengage Learning: Boston, MA, USA, 2017.

257. Lewin, K. The Kurt Lewin Model of Change. 1947. Available online: http://www.change-management-coach.com/kurt_lewin.html (accessed on 1 September 2020).

258. Orton, J.D. From inductive to iterative grounded theory: Zipping the gap between process theory and process data. Scand. J. Manag. 1997, 13, 419-438. [CrossRef]

259. Dinar, A.; Rosengrand, M.; Meizen-Dick, R. Water Allocation Mechanisms; Policy Research: Washigton, DC, USA, 1997.

260. Baumol, W.J. Equity vs. allocative efficiency: Toward a theory of distributive justice. Atl. Econ. J. 1978, 6, 9-16. [CrossRef]

261. Roemer, J.E. Theories of Distributive Justice; Harvard University Press: Cambridge, MA, USA, 1996.

262. Schubert, C.; Chai, A. Sustainable Consumption and Consumer Sovereignty; Papers on Economics and Evolution: Jena, Germany, 2012.

263. Briscoe, J. Water as an economic good The idea and what it means in practice. In Sixteenth World Congress International Commision on Irrigation and Drainage; International Commision on Irrigation and Drainage: Cairo, India, 1996; p. 25.

264. Hutt, W.H. Economists and the Public: A Study of Competition and Opinion; Jonathan Cape, Ltd.: London, UK, 1936.

265. Hutt, W.H. The Concept of Consumers' Sovereignty. Econ. J. 1940, 50, 66-77. [CrossRef]

266. Von Mises, L. Human Action: A Treatise on Economics, 4th ed.; Fox \& Wilkes: San Francisco, CA, USA, 1996.

267. Lerner, A.P. The Economics Consumer Politics of Sovereignty. Am. Econ. Rev. 1972, 62, 258-266.

268. Arrow, K.J. Social Choice E Individual Values, 2nd ed.; John Wiley \& Sons, Inc.: New York, NY, USA, 1970. 
269. Ward, F.A.; Michelsen, A. The economic value of water in agriculture: Concepts and policy applications. Water Policy 2002, 4, 423-446. [CrossRef]

270. Rose, N. Governing the Soul: The Shaping of the Private Self, 2nd ed.; Free Association Books: London, UK, 1999.

271. Brown, P.M.; Cameron, L.D. What can be done to reduce overconsumption? Ecol. Econ. 2000, 32, 27-41. [CrossRef]

272. Costanza, R.; Daly, H.E.; Bartholomew, J.A. Goals, agenda, and policy recommendations for ecological economics. In Ecological Economics: The Science and Management of Sustainability; Costanza, R., Ed.; Columbia University Press: New York, NY, USA, 1991; pp. 1-22.

273. Schumpeter, J.A. The Theory of Economic Development (Theorie der Wirtschaftlichen Entwicklung Translated by Redvers Opie); Transaction Publishers: Piscataway, NJ, USA, 1934.

274. Bator, F.M. The Anatomy of Market Failure. Q. J. Econ. 1958, 72, 351-379. [CrossRef]

275. Zerbe, R.O., Jr.; Mccurdy, H.E. The Failure of Market Failure. J. Policy Anal. Manag. 1999, 18, 558-578. [CrossRef]

276. Randall, A. The Problem of Market Failure. Nat. Resour. J. 1983, 23, 131-148.

277. Cornes, R.; Sandler, T. The Theory of Externalities, Public Goods, and Club Goods, 2nd ed.; Cambridge University Press: Cambridge, UK, 1996

278. Hardin, G. The Tragedy of the Commons. Sci. New Ser. 1968, 162, 1243-1248. [CrossRef]

279. Eckstein, O. Water-Resource Development: The Economics of Project Evaluation; Harvard University Press: Cambridge, MA, USA, 1958.

280. Saglam, Y. Supply-based dynamic Ramsey pricing: Avoiding water shortages. Water Resour. Res. 2015, 51, 669-684. [CrossRef]

281. Bellver-Domingo, A.; Hernández-Sancho, F.; Molinos-Senante, M. A review of Payment for Ecosystem Services for the economic internalization of environmental externalities: A water perspective. Geoforum 2016, 70, 115-118. [CrossRef]

282. Grafton, R.Q. Responding to the 'Wicked Problem ' of Water Insecurity. Water Resour Manag. 2017, 31, 3023-3041. [CrossRef]

283. Grafton, R.Q.; Garrick, D.E.; Horne, J. Water Misallocation: Governance Challenges and Responses; World Bank's Global Water Practice: Washington, DC, USA, 2017.

284. Van Der Zaag, P.; Savenije, H.H.G. Towards improved management of shared river basins: Lessons from the Maseru Conference. Water Policy 2000, 2, 47-63. [CrossRef]

285. Frederick, K.D. Adaptive responses to climate change: Demand management. In Proceedings of the First National Conference on Climate Change and Water Resources Management; Institute for Water Resources: Alexandria, VA, USA, 1993 ; pp. 54-60.

286. Winpenny, J.T. Demand management for efficient and equitable use. In Water: Economics, Management and Demand; Kay, M., Franks, T., Smith, L., Eds.; E \& FN SPON: London, UK, 2002; pp. 273-280.

287. Pigou, A.C. A Study in Public Finance; Macmillan/St Martin's: New York, NY, USA, 1947.

288. Meade, J.E. Mr. Lerner on The Economics of Control. Econ. J. 1945, 55, 47-69. [CrossRef]

289. Tintner, G. A Note on Welfare Economics. Econometrica 1946, 14, 69-78. [CrossRef]

290. Reder, M.W. Studies in the Theory of Welfare Economics; Columbia University Press: New York, NY, USA, 1948.

291. Musgrave, R.A. The Theory of Public Finance: A Study in Public Economy; McGraw-Hill: New York, NY, USA, 1959.

292. Pigou, A.C. Some Aspects of the Welfare State. Diogenes 1954, 2, 1-11. [CrossRef]

293. Bovenberg, L.A.; De Mooij, R.A. Environmental Levies and Distortionary Taxation. Am. Econ. Rev. 1994, 84, 1085-1089.

294. Diamond, P.A.; Mirlees, J.A. Optimal Taxation and Public Production I: Production Effciency. Am. Econ. Rev. 1971, 61, 8-27.

295. Stiglitz, J.E.; Dasgupta, P. Differential Taxation, Public Goods, and Economic Efficiency. Rev. Econ. Stud. 1971, 38, 151. [CrossRef]

296. Stiglitz, J.E. Addressing Climate through Price and Non-Price Interventions; NBER Working Paper Series Addressing; NBER: Cambridge, MA, USA, 2019.

297. Sandmo, A. Optimal taxation in the presence of Externalities Author(s). Swedish J. Econ. 1975, 77, 86-98. [CrossRef]

298. Buchanan, J.M. External Diseconomies, Corrective Taxes, and Market Structure. Am. Econ. Rev. 1969, 59, $174-177$.

299. Millenium Ecosystem Assessment. Ecosystems and Human Well-Being: Synthesis; Island Press: Washington, DC, USA, 2005.

300. Shoup, C.S. Principles of National Income Analysis; Houghton Mifflin Co.: Boston, MA, USA, 1947.

301. Rosegrant, M.W.; Binswanger, H.P. Markets in tradable water rights: Potential for efficiency gains in developing country water resource allocation. World Dev. 1994, 22, 1613-1625. [CrossRef]

302. Culp, P.W.; Glennon, R.; Libecap, G. Shopping for Water: How the Market Can Mitigate Water Shortages in the American West; Brookings Institution: Washington, DC, USA, 2014

303. Wildman, R.A.; Forde, N.A. Management of Water Shortage in the Colorado River Basin: Evaluating Current Policy and the Viability of Interstate Water Trading. J. Am. Water Resour. Assoc. 2012, 48, 411-422. [CrossRef]

304. Stern, C.V.; Sheikh, P.A. R45546 CRS Report Management of the Colorado River: Water Allocations, Drought and the Federal Role; Congressional Research Service: Washigton, DC, USA, 2020.

305. Savenije, H.; Van Der Zaag, P. Water as an Economic Good and Demand Management Paradigms with Pitfalls. Water Int. 2002, 27, 98-104. [CrossRef]

306. Dwyer, G.; Douglas, R.; Peterson, D.; Chong, J.; Maddern, K. Irrigation Externalities: Pricing and Charges; Productivity Commission Staff Working Paper; Productivity Commission: Melbourne, Australia, 2006.

307. Janmaat, J. Water applications and Pigouvian taxes to control irrigation-induced soil degradation. J. Dev. Econ. 2005, 76, 209-230. [CrossRef]

308. Albiac, J.; Calvo, E.; Kahil, T.; Esteban, E. The Challenge of Irrigation Water Pricing in the Water Framework Directive. Water Altern. 2020, 13, 674-690. 
309. Berbel, J.; Borrego-Marin, M.M.; Exposito, A.; Giannoccaro, G.; Montilla-Lopez, N.M.; Roseta-Palma, C. Analysis of irrigation water tariffs and taxes in Europe. Water Policy 2019, 21, 806-825. [CrossRef]

310. Renault, D.; Wahaj, R.; Smits, S. Multiple Uses of Water Services in Large Irrigation Systems: Auditing and Planning Modernization the MASSMUS Approach; FAO: Rome, Italy, 2013.

311. Baldock, D.; Caraveli, H.; Dwyer, J.; Einschütz, S.; Peteresen, J.E.; Sumpsi-Vinas, J.; Varela-Ortega, C. The Environmental Impacts of Irrigation in the European Union; Institute for European Environmental Policy: London, UK, 2000.

312. McNeill, D. Water as an economic good. Nat. Resour. Forum 1998, 22, 253-261. [CrossRef]

313. Tarlock, D.A. Prior Appropriation: Rule, Principle, or Rhetoric. N. D. Law Rev. 2000, 76, 30.

314. Lee, T. The Water Excise Tax: Preserving a Necessary Resource. Northwest. J. Law Soc. Policy 2009, 4, 171.

315. Owen, D. Water and Taxes. Univ. Calif. Davis Law Rev. 2017, 50, 1559-1617. 